\title{
Marek Kornat
}

https://orcid.org/0000-0003-2639-6974

Instytut Historii im. Tadeusza Manteuffla Polskiej Akademii Nauk

\section{Andrzej Walicki jako historyk idei}

Zarys treści: Bohaterem artykułu jest Andrzej Walicki, bez wątpienia najbardziej twórcza osobistość w kręgu tzw. warszawskiej szkoły historii idei. Zadaniem poniższych rozważań jest analiza jego wkładu do polskiej historiografii idei. Ukazane zostaną główne pola jego refleksji naukowej oraz najpoważniejsze osiągnięcia w takich obszarach, jak historia myśli rosyjskiej i polskiej XIX-XX w., teoria totalitaryzmu oraz historia marksizmu.

The content outline: The protagonist of this article is Andrzej Walicki, undoubtedly the most creative personality in the circle of the so-called Warsaw School of the history of ideas. The following reflections aim to analyse his contribution to the Polish historiography of ideas and present the main fields of his study together with the most significant achievements in the history of Russian and Polish thought of the nineteenth and twentieth centuries, the theory of totalitarianism and the history of Marxism.

Słowa kluczowe: Andrzej Walicki, historia idei, mesjanizm, idee narodu, Rosja, totalitaryzm

Keywords: Andrzej Walicki, history of ideas, Messianism, ideas of the nation, Russia, totalitarianism

Długie i niezwykle owocne życie prof. Andrzeja Walickiego przyniosło bogaty plon studiów i prac $\mathrm{z}$ historii idei. $Z$ całą pewnością inteligencja polska łączy jego nazwisko przede wszystkim z tym wielkim tematem poszukiwań badawczych, jakim była dla niego Rosja. Mam oczywiście na myśli rosyjską myśl - filozoficzną, polityczną, społeczną i religijną. Byłoby jednak bardzo zubażające nie powiedzieć, że chociaż istotnie sprawy te stanowiły centralny obiekt zainteresowań autora $W$ kregu konserwatywnej utopii, to jednak wkroczył on jeszcze na kilka wielkich pól badawczych, a było ich przynajmniej trzy: (1) dzieje polskiej myśli politycznej (społecznej) - doby porozbiorowej, (2) sprawy marksizmu jako formacji intelektualnej, która tak wydatnie naznaczyła dzieje nowoczesnej Europy i świata, (3) totalitaryzm jako pojęcie i zarazem koncepcja historiograficzna. Ale i na tym nie koniec, Profesor zaznaczył bowiem swoją obecność i na innych - może mniej zasadniczych dla niego, lecz jakże ważnych dla nas - obszarach dociekań: 
(1) liberalizm jako idea polityczna, (2) nacjonalizm i problem narodu, (3) tradycje polskiego patriotyzmu czy wreszcie (4) sprawy inteligencji jako fenomenu polskiej historii doby porozbiorowej i dwudziestowiecznej. Powiedzieć w jednym artykule o tym wszystkim jest zupełnie niemożliwe. Albo groziłoby to banalnością, albo byłoby nader pobieżne. Zamysł niniejszego szkicu wyrasta więc z przekonania, że w twórczości Walickiego najważniejsze pozostaje to wszystko, co powiedział on z problematyki dziejów myśli rosyjskiej, po tym - w hierarchii - idą prace z porozbiorowej polskiej myśli politycznej, studia z dziejów marksizmu oraz dociekania wokół totalitaryzmu. I o tych sprawach chciałbym na tym miejscu coś powiedzieć - oczywiście czyniąc to ze świadomością, że ten czołowy polski historyk idei doczekał się już kilku interesujących naświetleń swej twórczości ${ }^{1}$.

\section{Osobowość i historia}

Andrzej Walicki nie miał mistrza. Tadeusza Krońskiego nie stawiał nigdy zbyt wysoko, zawsze uważając, że nie pozostawił on po sobie właściwie żadnego dorobku intelektualnego ${ }^{2}$. Wiele zawdzięczał - jak zwykł był mówić - rosyjskiemu filozofowi, emigrantowi w Polsce, Sergiuszowi Hessenowi, i Tadeuszowi Kotarbińskiemu, a w jakiejś mierze i Stanisławowi Ossowskiemu³. Wiąże się nazwisko Walickiego z tym fenomenem w polskim powojennym życiu umysłowym, jakim była warszawska szkoła historyków idei. Jest to słuszne, ale i w tym kręgu (obok Bronisława Baczki, Leszka Kołakowskiego czy Jerzego Szackiego) zajmował on stanowisko dość szczególne - choćby przez znamienne dowartościowanie problematyki narodu jako najbardziej pojemnej wspólnoty wartości, jaką wytworzyła historia ${ }^{4}$.

${ }^{1}$ Wokół twórczości Andrzeja Walickiego powstało już kilka naświetleń w historiografii. Mam tu na myśli przede wszystkim przygotowany na jego 75-lecie tom: Wokót Andrzeja Walickiego. Almanach myśli rosyjskiej, red. J. Dobieszewski, J. Skoczyński, M. Bohun, Warszawa 2009. Zawiera on szkice i artykuły trzech wyżej wspomnianych oraz Włodzimierza Rydzewskiego, Bronisława Łagowskiego, Pawła Kozłowskiego, Ryszarda Sitka, Jana Krasickiego, Leszka Augustyna, Marka Styczyńskiego i Andrzeja de Lazariego. Trudno nie wspomnieć innych ujęć, jak choćby to Andrzeja Mencwela, dane jako wstęp do A. Walickiego, Polski, Rosji, marksizmu, red. A. Mencwel, Kraków 2011 (Kultura i Myśl Polska. Prace Wybrane Andrzeja Walickiego, 4). Odsyłam też i do moich dwóch szkiców: Andrzej Walicki i doświadczenie totalitaryzmu. O użyteczności historii idei, „Przegląd Polityczny" 2010, nr 102, s. 60-79; Marksizm a totalitaryzm. Wokót stanowiska Andrzeja Walickiego, „Przegląd Filozoficzny” (nowa seria) 20, 2011, nr 1(77), s. 47-61.

2 Znamienny jest tu esej „Tygrys” $i$ „odwilz” zawarty w tomie Spotkania $z$ Miłoszem (Londyn 1983), a potem w Zniewolonym umyśle po latach (Warszawa 1993).

${ }^{3}$ Hessena określił po latach jako „duchowego mistrza z lat młodości”; zob. wstęp do A. Walicki, Zarys myśli rosyjskiej. Od oświecenia do renesansu religijno-filozoficznego, Kraków 2005, s. 13 (wyd. ang.: The Flow of Ideas. Russian Thought from the Enlightenment to the Religious-Philosophical Renaissance, tłum. J. Kozak, H. Andrews-Rusiecka, Frankfurt am Main 2015).

${ }^{4}$ Najpierw zabrał głos na ten temat Paweł Śpiewak artykułem: W pół drogi. Warszawska szkoła historyków idei, „Więź” 1981, nr 5, s. 39-48. Najszerzej omówił ten fenomen Ryszard Sitek: 
W 1947 r. podjął decyzję o studiach filozoficznych. Łączyło się to z wyobrażeniem, że kiedyś stworzy „historię systemów etycznych jako różnych sposobów nadawania sensu życiu i że praca nad tym dziełem" będzie pomocna do uzasadnie-

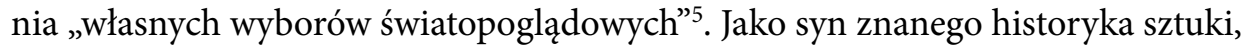
związanego z Biurem Informacji i Propagandy Komendy Głównej Armii Krajowej, w dobie stalinowskiej studiów filozoficznych podjąć nie mógł. Miał możliwość je rozpocząć na rusycystyce - w Łodzi, na nowo tam powstałym uniwersytecie. Już po roku przeniósł się na studia filozoficzne w Warszawie. Wybór Rosji okazał się trwałą opcją. Tak stał się świetnym znawcą myśli rosyjskiej, przedzierając się samodzielnie przez jej jakże bogate dziedzictwo - z wielkim oddaniem i empatią, całkowicie przezwyciężywszy stereotyp rosyjskiej niższości cywilizacyjnej, jakże żywy w kołach polskiej inteligencji doby porozbiorowej i w II Rzeczypospolitej, z której kręgów przecież wyrósł.

Walicki - jak sam powie w swoich wspomnieniach pt. Zniewolony umysł po latach nigdy nie był z przekonań marksistą, ale nieobce mu było doświadczenie racjonalizacji „nowej wiary”, którą wspiera „logika dziejów”, a w tym i Miłoszowskiego ketmana, czyli gry, jaką prowadzi jednostka, zmagając się z tą wiarą. Wolno sądzić, iż to właśnie pomogło mu zrozumieć fenomen rządów ideokratycznych, których zrozumienie daje rozeznanie o istocie władzy totalitarnej. Pojęciu „,ideokracji” nie poświęcamy tu więcej miejsca, ale warto odnotować, że impuls do jego stworzenia dał Nikołaj Bierdiajew, później propagował je na Zachodzie Waldemar Gurian ${ }^{6}$.

Nota bene Czesław Miłosz, poznawszy Walickiego w Kalifornii na początku lat 60 . XX w., uznał, że poglądy jego to potwierdzenie, iż „Zniewolonego umysłu nie wyssałem z palca - jak napisał do Jerzego Giedroycia. - Była pewna ilość ludzi, którzy tak to przeżywali jak opisałem. Historycznie - jest to dowód istnienia pewnego umysłowego środowiska, b. ważnego w pewnym sensie. Kołakowski bez tego byłby niezrozumiały”?

Na Uniwersytecie Warszawskim ukończył studia w 1953 r. Przypadło to na szczyt sowietyzacji humanistyki polskiej. Czasy te opisał Profesor w książce sumującej wszelkie jego wspomnienia: Idee i ludzie. Próba autobiografii (2010), którą

Warszawska szkoła historii idei: między historiq a teraźniejszościq, Warszawa 2000. O tej formacji intelektualnej pisał też Andrzej Mencwel: Warszawska szkoła historyków idei - powstanie, przekształcenia, kontynuacje, „Przegląd Humanistyczny” 2012, nr 3, s. 5-38. Walicki odniósł się do tego dla siebie autobiograficznego tematu w szkicu: Warszawska szkoła historyków idei: kilka sprostowań i pytań, „Przegląd Polityczny” 2015, nr 129, s. 54-67. W ostatnim czasie wreszcie wyszedł tom materiałów: Archiwum warszawskiej szkoły historii idei, wstęp, red. i oprac. A. Karalus, P. Parszutowicz, Warszawa 2015.

5 A. Walicki, Idee i ludzie. Próba autobiografii, Warszawa 2010, s. 27.

${ }^{6}$ N. Bierdiajew, Problemy komunizmu, tłum. M. Reutt, Warszawa 1937; W. Gurian, The Totalitarianism as Political Religion, w: Totalitarianism, red. C.J. Friedrich, Cambridge (MA) 1954, s. $119-140$.

7 Zob. J. Giedroyc, C. Miłosz, Listy 1973-2000, oprac. M. Kornat, Warszawa 2012, list C. Miłosza do J. Giedroycia, 23 I 1984 r., s. 328. 
opatrzył mottem z Wilhelma Diltheya: „w autobiografii spotykamy się z najwyższą i najbardziej pouczającą formą rozumienia życia"8.

Walicki zdobył doktorat w rok po przełomowym przewrocie 1956, który dał Polakom jakże wiele, chociaż nie przyniósł niepodległości. Książka będąca raczej zbiorem studiów niż monografią - zatytułowana Osobowość a historia. Studia $z$ dziejów literatury i myśli rosyjskiej (Warszawa 1959) - zaprogramowała na swój sposób dalsze poszukiwania i działania Walickiego, czyniąc go mającym przed sobą przyszłość autorem ważnych dociekań ${ }^{9}$. Od razu dopowiedzmy, że rusycystyka polska miała oczywiście wielu filologów, ale niewielu było właśnie historyków idei potrafiących czytać dzieła literackie jako pisma wyrażające określone wizje ładu społecznego i hierarchii wartości, która go porządkuje bądź winna kształtować.

Habilitacja Andrzeja Walickiego doszła do skutku w Instytucie Filozofii i Socjologii Polskiej Akademii Nauk w 1964 r. Wydana w tym roku rozprawa $W$ kręgu konserwatywnej utopii. Struktury i przemiany rosyjskiego słowianofilstwa przynosiła znaczącą monografię. Dała solidną porcję przemyśleń. Prezentowała nowe naświetlenie wyobraźni politycznej rosyjskich myślicieli i pisarzy - właśnie jako „konserwatywnej utopii”, utopii retrospektywnej, która kształtuje wyobrażenia ludzkie o przyszłości. Jest fenomenem „retrospekcji przewrotowe”” (według określenia Kazimierza Kelles-Krauza).

Po Bronisławie Baczce - usuniętym ze stanowiska w czasie represji antyinteligenckich i antysemickich, jakie przyniósł Marzec 1968 r. - objął Walicki kierownictwo Zakładu przekształconego następnie w Zespół Historii Nowożytnej Filozofii Polskiej w Instytucie Filozofii i Socjologii PAN w Warszawie, którym kierował w latach 1968-1976. Wybór ten do dzisiaj pozostaje niewolny od wątpliwości, które można podnosić. Ale jakże był słuszny i owocny dla humanistyki polskiej!

Od wkroczenia w życie akademickie za sprawą rozprawy Osobowość a historia do wyjazdu z kraju w 1981 r. upłynęło w życiu Walickiego 22 lata. Kończył akademicką karierę w Polsce. Wyjeżdżał za granicę, po polskim Sierpniu, w gorących dniach przełomu, jaki dokonywał się za sprawą „Solidarności”. Nie czuł tych wydarzeń - jak sam to powiedział - jako rewolucji moralnej, którą tak właśnie wielu postrzega, rozpamiętując tamte chwile.

W Australii - na Uniwersytecie Narodowym w stolicy kraju Canberze - obją stanowisko wykładowcy. Tam wznowił pracę naukową. Trwało to pięć lat. W $1986 \mathrm{r}$. odszedł, aby na trzynaście lat osiąść w amerykańskiej Indianie - na katolickim (prowadzonym przez jezuitów) Uniwersytecie Notre Dame. Do 1999 r. był tam profesorem. Dało to kilka znaczących książek, które wprowadził do amerykańskiego życia umysłowego. Dwie z nich pozostaną z pewnością najważniejsze: Legal

${ }^{8}$ A. Walicki, Idee i ludzie..., s. 11.

9 Walicki używał będzie już ex post sformułowania „program życiowy”; zob. tenże, Zniewolony umyst po latach, Warszawa 1993, s. 43. 
Philosophies of Russian Liberalism (1987 i 1992) oraz Marxism and the Leap to the Kingdom of Freedom. The Rise and Fall of the Communist Utopia (1995). Polskie zmagania o wolność, ale i „z wolnością” oglądał „z boku”10.

Do Warszawy powracał po blisko dwudziestu latach - w nowej już rzeczywistości Polski po przewrocie 1989 r., mając za sobą to wszystko, co się wydarzyło w kraju jako non-belonger ${ }^{11}$. I tej nowej Polski był surowym krytykiem. Ostatnie dwadzieścia lat życia poświęcił w znacznej mierze nowym pomysłom - żywo reagując na wyzwania nowych czasów, co jednak stanowi temat na osobne rozważania.

\section{Myśl rosyjska i polska}

Próbując coś powiedzieć o Andrzeju Walickim, wręcz nie wolno zapomnieć o tym, jak niełatwo było w czasach początków jego twórczości pisarskiej podejmować sprawy myśli rosyjskiej. Świadomość wielkiej tradycji kultury rosyjskiej, a zwłaszcza dylematów i dramatów rosyjskich myślicieli XIX stulecia była w świadomości inteligencji polskiej niezmiernie ograniczona. Hasło przyjaźni polsko-radzieckiej było tylko emblematem. Panowało totalitarne ujarzmienie myśli ludzkiej. W latach stalinizacji Polski jakakolwiek samodzielna interpretacja myśli rosyjskiej była w ogóle trudna do wyobrażenia. Panowała urzędowa teza sowiecka, iż sprawy te zostawić należy „nauce radzieckiej”, która nie tylko wyprzedza swoimi dokonaniami wszelką „naukę burżuazyjną”, ale i winna być wzorcem dla humanistyki krajów „demokracji ludowej”. Koncepcje nauki sowieckiej należało tylko naśladować. Jakakolwiek dyskusja nie wchodziła w rachubę.

Choćby teoria o „rewolucyjnych demokratach” pozostaje tu dobrym przykładem tej zależności. Już po latach Walicki napisał: „Musiałem przeczytać dziesiątki radzieckich prac o Bielińskim i innych »rewolucyjnych demokratach" i to właśnie stało się jednym z czynników, które najmocniej uświadomiły mi całą grozę konsekwentnego totalitaryzmu. Przerażający był nie tyle prymitywizm tych prac, ten bowiem bywał niekiedy zabawny i rozweselający, ile fakt, że wszystkie one były podobne do siebie jak dwie krople wody - ten sam schemat, te same gromy rzucane na »kosmopolitów «, te same cytaty, [...] ta sama uniformizacja myśli"12.

Pierwsze prace z rosyjskiej historii intelektualnej stworzył Walicki jeszcze przed „odwilżą". Trzeba bowiem wspomnieć o jego obszernych wprowadzeniach do pism Mikołaja Gogola - Rewizora (1953) i Martwych dusz (1956). Przewrót, jaki przyniósł

${ }^{10}$ Cytuję tu tytułowe sformułowania tomu publicystyki Profesora: Polskie zmagania $z$ wolnością. Widziane z boku, Kraków 2000.

11 Korzystam tu z tytułowego sformułowania we wspomnieniowej książce Richarda Pipesa (Vixi. Memoirs of a Non-Belonger, New Haven 2003).

12 A. Walicki, $W$ kręgu konserwatywnej utopii. Struktura i przemiany rosyjskiego słowianofilstwa, Warszawa 2002, s. 450 (posłowie napisane w 2001). 
polski Październik 1956 r., dał mu pierwszą możliwość istotnego wystąpienia na polu studiów nad myślą rosyjską. W 1958 r. napisał Walicki niezmiernie ważną rozprawę Od narodnictwa do leninizmu ${ }^{13}$. Stworzył ją na seminarium Stanisława Ossowskiego. Tekst ukaże się jednak drukiem dopiero po latach - w tomie studiów Idea wolności u myślicieli rosyjskich. Studia z lat 1955-1959 (Kraków 2000).

Na lata 1953-1959 przypada pierwsza faza studiów Walickiego z zakresu historii myśli rosyjskiej. Mają one czytelną myśl przewodnią - ideę wolności u rosyjskich myślicieli XIX stulecia ${ }^{14}$. Liczący sobie 26 lat historyk idei wydał oto książkę Osobowość a historia. Studia z dziejów literatury i myśli rosyjskiej. Był tok 1959. Praca nie stanowiła monografii, lecz zbiór studiów. Zapowiadał autor wielki program studiów nad intelektualnymi dziejami Rosji XIX stulecia - aż po Lenina i rewolucję październikową. Programowi temu będzie Walicki wierny do końca - do śmierci - przez całe sześćdziesiąt lat pracy akademickiej. Dodajmy w tym miejscu, że od czasów Mariana Zdziechowskiego (zm. 1938) historii idei z takim rozmachem jak Andrzej Walicki nikt w Polsce nie uprawiał.

Przyświecała tu Walickiemu idea swoistej misji. Wypowiedział to niezwykle jasno w liście do Czesława Miłosza w grudniu 1960 r.: „Piszę bardziej może dla Rosjan niż dla Polaków, chociaż wiem, że oni nie będą mnie czytać. Byłbym szczęśliwy, gdybym mógł pomóc Rosjanom w odzyskaniu ich najcenniejszej tradycji, zagubionych i sponiewieranych tradycji niepokoju moralnego"15. Zaznaczmy jeszcze, że w przekonaniu tym umacniał go Isaiah Berlin. Doradzał mu w ogóle nie przejmować się tym, co sądzi o tym pisarstwie nauka sowiecka, gdyż to jest bez znaczenia. Między polskim historykiem idei a autorem Dwóch koncepcji wolności wytworzyła się swoista więź „moralno-intelektualna”. A jej podstawą był stosunek do Rosji ${ }^{16}$. Dodajmy ponadto, że na emigracji z uznaniem i zrozumieniem dla tych wysiłków badawczych, jakie podejmował Walicki nad myślą rosyjską, odnosili się znani intelektualiści polscy: Aleksander Hertz, Wiktor Weintraub, Wiktor Sukiennicki czy Wacław Lednicki.

Pięć lat po publikacji tomu studiów Osobowość a historia wydał Andrzej Walicki nową książkę - jedną z najważniejszych w swoim życiu. Mam oczywiście na myśli monografię $W$ kregu konserwatywnej utopii. Struktury i przemiany rosyjskiego słowianofilstwa (1964). Od czasu ważnej książki Zdziechowskiego Mesjaniści i słowianofile (1887) - dającej umiejętny pokaz analizy komparatystycznej - nie ukazała się w Polsce praca o tak szerokim ujęciu problemu. Powstało dzieło dużej wagi.

Po mniej więcej piętnastu latach intensywnej pracy intelektualnej nad rosyjską myślą społeczną dał Andrzej Walicki wielką syntezę Rosyjska filozofia i myśl

${ }^{13}$ Jest to w istocie zwięzłe studium będące konspektem nienapisanej książki.

14 Teksty zebrał Walicki po latach w jednym tomie: Idea wolności u myślicieli rosyjskich. Studia z lat 1955-1959, Kraków 2000 (Jagiellońskie Studia z Filozofii Rosyjskiej, 3).

15 A. Walicki, Spotkania z Miłoszem, Londyn 1983, s. 98.

16 Tenże, Idea wolności u myślicieli rosyjskich..., list z 13 III 1962 r., s. 279, 287. 
społeczna od oświecenia do marksizmu (1973) ${ }^{17}$. Wykład swój poprowadził autor w taki sposób, aby nie dać poznać swoich preferencji ideowych. Potrafił z równym akademickim dystansem spojrzeć na idee Piotra Czaadajewa, Nikołaja Danilewskiego, Gieorgija Plechanowa czy Włodzimierza Lenina.

Jak napisze po latach autor, to Sergiuszowi Hessenowi i Isaiah Berlinowi najwięcej zawdzięczał, pisząc tę książkę. Otrzymał za nią włosko-szwajcarską Nagrodę Eugenia Balzana za $1998 \mathrm{r}^{18} \mathrm{~W}$ przedmowie do przekładu książki, który ukazał się pt. A History of Russian Thought from the Enlightenment to Marxism (1979), stwierdzał, że powstała ona jako „produkt warszawskiej szkoły historyków idei” ${ }^{19}$. Pisząc wstęp do tej książki, podkreślał, jak ważne jest „empatyczne zrozumienie kultury rosyjskiej”, które „w Polsce ma żywotne znaczenie”20. Wspomniał znanego działacza polskiego ruchu robotniczego i historyka idei Ludwika Kulczyckiego za sprawą jego książki Rewolucja rosyjska. Od dekabrystów do wędrówki w lud 1825-1870 (t. 1-2, Lwów 1909). Przypominał Stanisława Brzozowskiego jako autora pierwszej powieści o Narodnej Woli (Płomienie). Składał hołd jeszcze dwóm postaciom za ich wyjątkowe zrozumienie rosyjskiej filozofii religijnej - czeskiemu profesorowi i mężowi stanu Tomaszowi Garrigue Masarykowi i „polskiemu myślicielowi katolickiemu" (którego tak określał) Marianowi Zdziechowskiemu ${ }^{21}$.

Po latach Walicki powrócił do tej wielkiej syntezy dziejów myśli rosyjskiej, dając w znacznej mierze nowe jej ujęcie w 2005 r.: Zarys myśli rosyjskiej. Od oświecenia do renesansu religijno-filozoficznego. Właśnie renesans religijny i ten fenomen, który historiografia nazywa srebrnym wiekiem myśli rosyjskiej, objął tymi rozważaniami, o wprowadzeniu których do książki z 1973 r. trudno było pomyśleć. Nowe ujęcie stworzył „Z zachowaniem interpretacyjnej ciągłości” tych problemów, które rozpatrywał w wydaniu z 1973 r. Powstało przedstawienie znacznie rozszerzone. Uderza stwierdzenie Walickiego zawarte $\mathrm{w}$ przedmowie, iż nie musiał niczego zmieniać w tekście pierwszego wydania, bo „od samego początku bowiem pisany był [on] z pozycji maksymalnej niezależności od obowiązujących w ZSRR schematów interpretacyjnych"22. Nowe rozdziały końcowe pozwoliły objąć jeszcze całą pierwszą dekadę XX w., a więc kryzys marksizmu, renesans religijno-filozoficzny, neoidealizm i neoliberalizm. Wykład doprowadzony został do mniej więcej lat 1910-1912. Swoich rozważań nie doprowadził do 1917 r., argumentując, że w dziejach myśli rosyjskiej przewrót bolszewicki nie stanowi cezury zwrotnej.

17 Drugie, poszerzone wydanie tego dzieła ukazało się w 2005 r. w t. 10 serii Jagiellońskie Studia z Filozofii Rosyjskiej.

${ }^{18}$ Był jedynym Polakiem odznaczonym tym wyróżnieniem, przyznawanym od $1961 \mathrm{r}$.

${ }_{19}$ Fragmenty tej przedmowy cytuje Walicki w swoim wprowadzeniu do Zarysu myśli rosyjskiej..., s. 11.

20 Tamże.

21 Tamże.

22 Tamże, s. 13. 
Filozofia prawa rosyjskiego liberalizmu - pisana w Ameryce i wydana w $1992 \mathrm{r}$. po angielsku - to $\mathrm{w}$ zasadzie ostatnia wielka książka Walickiego z problematyki historii intelektualnej Rosji. Przynosiła zupełnie nowe spojrzenie na dzieje rosyjskiej myśli politycznej, podważając wpływowy, a będący uproszczeniem pogląd o całkowitym braku tradycji liberalnej w Rosji przedrewolucyjnej. Filozofia prawa rosyjskiego liberalizmu dowodziła, że „Rosja miała jednak tradycje, które mogłaby przeciwstawić bolszewizmowi" ${ }^{23}$.

Odnotujmy jeszcze, że w Zarysie myśli rosyjskiej. Od oświecenia do renesansu religijno-filozoficznego osobną uwagę poświęcił Walicki konserwatywnej filozofii polityki międzynarodowej, której manifestem pozostaje napisany ręką cara Aleksandra I tekst deklaracji założycielskiej Świętego Przymierza. Ów dokument ideowo "gęsty” - jak powie Walicki, dawał określoną wizję ładu międzynarodowego w duchu chrześcijańskiego uniwersalizmu ${ }^{24}$. Autor tej deklaracji, zarówno politycznej, jak i religijnej, wprowadzał myśl o „powszechnym poczuwaniu się do przynależności do jednego narodu chrześcijańskiego" i głosił, że przy tym „trzej książęta sprzymierzeni sami uważają się tylko za wyznaczonych przez Opatrzność do rządzenia trzema gałęziami tej samej rodziny - a mianowicie Austrią, Prusami i Rosją, wyznając przez to, że naród chrześcijański, w którego skład wchodzą oni i ich ludy, ma w istocie jednego Pana, który sam tylko posiada władzę, bo w Nim jedynie tkwią wszystkie skarby miłości, wiedzy i mądrości nieskończonej"25. Dodajmy, że Święte Przymierze - bez względu na nasze polskie uprzedzenia związane $\mathrm{z}$ narodową niewolą - było pierwszą $\mathrm{w}$ historii realną organizacją, przez stworzenie której usiłowano Europie dać polityczną jedność w dobie nowożytnej, kiedy chrześcijański uniwersalizm średniowiecza należał bezpowrotnie do przeszłości.

Tę sekwencję zasadniczych wypowiedzi z problematyki dziejów rosyjskiej myśli społecznej zamyka tom studiów Rosja, katolicyzm i sprawa polska, ogłoszony drukiem w $2002 \mathrm{r}$. Znaczące miejsce na tych kartach zajmuje sprawa relacji katolicyzm - prawosławie. Dużo uwagi poświęcił Walicki przenikliwym wizjom Włodzimierza Sołowiowa, orędownika pojednania Kościołów Wschodu i Zachodu, rzecznika wizji zjednoczenia chrześcijaństwa, w których dopatrywał się inspiracji współczesnej przede wszystkim w nauczaniu papieża Jana Pawła $\mathrm{II}^{26}$.

Podróż w czasie, jaką odbył Walicki od książki Osobowość a historia po tom Rosja, katolicyzm i sprawa polska, daje niezwykły w swym rodzaju pokaz samodzielnego odkrywania dziejów myśli rosyjskiej. Nie ma nikogo, kto pod tym względem mógłby z nim współzawodniczyć czy też prowadzić takie studia

${ }^{23}$ A. Walicki, Kartki z dziennika, w: tenże, Polskie zmagania z wolnością..., s. 406.

${ }^{24}$ Tenże, Zarys myśli rosyjskiej..., s. 96 (omówienie tych projektów na s. 92-97).

25 Cyt. za: Prawo międzynarodowe i historia dyplomatyczna, t. 1, red. L. Gelberg, Warszawa 1958, s. 26-27.

${ }^{26}$ Walicki wskazywał tu zwłaszcza na encykliki Slavorum apostoli (1985) i Ut unum sint (1995). 
w sposób paralelny. Z tej perspektywy patrząc, wymienić można jedynie pisma Isaiah Berlina - przede wszystkim jego studia wydane pt. Russian Thinkers ${ }^{27}$.

„Proszę nie opuszczać myślicieli rosyjskich” - pisał do Walickiego Isaiah Berlin w liście z 13 marca 1962 r. ${ }^{28}$ Polski profesor ich nie opuścił, ale wkroczył na pole myśli polskiej. I z pewnością polska myśl polityczna i społeczna doby porozbiorowej nie doczekała się przed nim żadnego badacza, który by z taką rozległością horyzontów i konsekwencją podjął i prowadził wieloletnie nad nią studia. Nie było to zadanie łatwe. Porozbiorowe dzieje Polski zawsze przyciągały uwagę historyków. Były polem wielu studiów i rozważań, ale myśl polityczna i społeczna doby niewoli wymagała z całą pewnością nowych studiów - mimo tych dokonań historyków idei, na które przyszła pora już w II Rzeczypospolitej ${ }^{29}$.

Trudno nie podkreślić, że poważne podjęcie spraw polskiej myśli politycznej doby porozbiorowej wymagało $w$ realiach PRL przede wszystkim zwrócenia się przeciw funkcjonującym w historiografii polskiej, a narzuconym zapożyczeniom z nauki sowieckiej, które wyrażały choćby pojęcia "rewolucyjnych demokratów” czy „rewolucji agrarnej”. To samo powiedzieć musimy o arbitralnie zadekretowanych kryteriach postępowości, bez stosowania których nie mogła się odbywać praca nad wszelką myślą polityczną czy społeczną ${ }^{30}$. Sprawy nie ułatwiał stereotyp prowincjonalności polskiej myśli politycznej i społecznej doby porozbiorowej. Opierał się on na tezie, iż była to myśl ogólnie jednowymiarowa. Wszystko podporządkowywano sprawie walki o niepodległość państwową. Jest wielką zasługą Andrzeja Walickiego, że potrafił to przezwyciężyć. Zdołał wydobyć z polskiej myśli politycznej i społecznej doby narodowej niewoli bardzo wiele spraw nowych. Nikt nie będzie w stanie przejść nad tymi ustaleniami i naświetleniami do porządku, jeśli kiedykolwiek wkroczy na to pole pod względem badawczym.

Wielce znaczącym faktem stało się w intelektualnej biografii Walickiego wspomniane już powierzenie mu w 1968 r. kierownictwa Zakładu Filozofii Polskiej w Instytucie Filozofii i Socjologii Polskiej Akademii Nauk - po Bronisławie Baczce ${ }^{31}$.

27 Książka wyszła w 1978 r., pol. wyd.: Rosyjscy myśliciele, tłum. S. Kowalski, posł. A. Walicki, Warszawa 2003.

28 A. Walicki, Idea wolności u myślicieli rosyjskich..., s. 287.

29 Pojawiły się ważne studia - stworzone metodą historii idei. Tytułem przykładu pozostaje wspomnieć choćby rozprawę Józefa Ujejskiego: Dzieje polskiego mesjanizmu do powstania listopadowego włącznie (Warszawa 1931). Zofia Klarnerówna ogłosiła studium: Słowianofilstwo w literaturze polskiej (Warszawa 1926). Adam Żółtowski przygotowywał dużą pracę o Auguście Cieszkowskim, ale jej ostatecznie nie stworzył.

30 Walicki polemicznie zwracał się przeciw tym uproszczeniom w referacie Marks $i$ Engels o sprawie polskiej. Uwagi metodologiczne, wygłoszonym w Warszawie na sesji naukowej w stulecie wybuchu powstania listopadowego. Tekst opublikowany pt. Rewolucyjność kwestii polskiej $i$ wynikające stąd konsekwencje, w: A. Walicki, Polska, Rosja, marksizm... (2011), s. 165-175.

31 Do tych spraw dużo przemyśleń dał Walicki w swej książce Idee i ludzie... 
Stanowisko to wiązało się z jego jakże licznymi inicjatywami wydawniczymi. Owocowało dziełami, które weszły do polskiej historiografii idei.

Już w artykule Mesjanistyczne koncepcje narodu i późniejsze losy tej tradycji z 1977 r. pisał Andrzej Walicki o swoistym zderzeniu oświecenia i romantyzmu, które $\mathrm{w}$ realiach polskich było $\mathrm{w}$ istocie starciem dwóch uniwersalizmów. $Z$ jednej strony był to uniwersalizm oświecenia poprzez uniformizację, z drugiej zaś - uniwersalizm romantyzmu przez harmonijną koegzystencję różnorodnych wspólnot (a więc narodów) o własnej odrębności i „nieprzemiennej tożsamości” - jak to trafnie ujął².

W polskiej właśnie myśli porozbiorowej dochodzi do głosu mocna świadomość, że naród nie jest „tożsamy z ludnością państwa”, ale jest to byt mający „zbiorową indywidualność" ${ }^{33}$. Ta konstatacja z 1977 r. ma swoje pełne uzasadnienie. Pozostaje też zgodna z obserwacjami historyków idei. „Naród historyczny, taki jak Polacy [...] stał się doskonałym modelem dla wszystkich pojawiających się narodów, którym brakowało takich warunków wstępnych, jakie mieli Polacy" - napisze Roman Szporluk ${ }^{34}$. Inspirowane ideami europejskiego oświecenia porozbiorowe polskie koncepcje narodu pokazał bardzo kompetentnie - i co najważniejsze - na tle porównawczym w książce The Enlightenment and the Birth of Modern Nationhood. Polish Political Thought from Noble Republicanism to Tadeusz Kościuszko ${ }^{35}$.

Wyróżnia się swoją przenikliwością i pomysłowością interpretacyjną słabo dzisiaj obecna w naszych polskich dyskusjach historycznych książeczka Walickiego Trzy patriotyzmy. Trzy tradycje polskiego patriotyzmu i ich znaczenie wspótczesne. Ów tekst bardzo szczególny, poświęcony oddziaływaniu przed- i porozbiorowych tradycji patriotyzmu polskiego na świadomość polską, przywiódł autora do zasadniczych rozróżnień. Wyodrębnił on mianowicie: (1) „patriotyzm woli narodowej”, (2) „patriotyzm idei narodowej” oraz (3) „patriotyzm interesu narodowego" ${ }^{36}$. Koncepcja Walickiego bardzo wydatnie inspiruje również dzisiaj. Kontynuując jego perspektywę, pozwoliłem sobie przed dziesięciu laty skorzystać z niej, pisząc o tradycjach i formach polskiego patriotyzmu doby II Rzeczypospolitej. Na marginesie

32 A. Walicki, Mesjanistyczne koncepcje narodu i późniejsze losy tej tradycji, w: Idee i koncepcje narodu w polskiej myśli politycznej czasów porozbiorowych, red. J. Goćkowski, A. Walicki, Warszawa 1977, s. 85.

${ }^{33}$ Tenże, Idee słowiańskie i filozoficzny romantyzm przed Powstaniem Listopadowym, w: S. Borzym, H. Floryńska, B. Skarga, A. Walicki, Zarys dziejów filozofii polskiej 1815-1918, Warszawa 1983, s. 16. Przedmowę do tej pracy oddał Walicki do druku tuż przed wyjazdem z kraju w czerwcu $1981 \mathrm{r}$.

${ }^{34}$ R. Szporluk, Polska: powstanie teorii i praktyki nowoczesnego narodu, w: tenże, Imperium, narody, komunizm. Wybór esejów, wstęp i oprac. A. Nowak, tłum. S. Czarnik, A. Nowak, Kraków 2003, s. 39.

${ }^{35}$ Notre Dame (Ind.) 1989 (wyd. pol.: Idea narodu w polskiej myśli oświeceniowej, Warszawa 2000).

${ }^{36}$ A. Walicki, Trzy patriotyzmy. Trzy tradycje patriotyzmu polskiego i ich znaczenie współczesne, Warszawa 1991, s. 7. Tekst był wielokrotnie później wznawiany. 
można dodać, że inny badacz tych zagadnień, Andrzej Nowak, w poszukiwaniach swoich wyodrębnił również trzy odmiany patriotyzmu polskiego: „patriotyzm republikański”, „patriotyzm imperium” i „patriotyzm modernizacyjny”37. Obie propozycje wciąż mogą inspirować. To owocne pole dociekań, jakim są tradycje patriotyzmu polskiego, wciąż pozostaje otwarte. Walicki je nakreślił pierwszy swoim szkicem Trzy patriotyzmy.

Adamowi Jerzemu Czartoryskiemu nie poświęcił Walicki osobnego studium w postaci książki, lecz powracał do jego myśli wielokrotnie. Widział w nim przedstawiciela politycznego obozu o obliczu nie konserwatywnym, ale raczej liberalnym. Odnotowywał oczywiście pionierskie wyartykułowanie idei nienaruszalności praw narodów, które z pewnością należy uznać za jedno z najważniejszych osiągnięć Czartoryskiego jako pisarza politycznego i autora teorii „legitymizmu narodów”. Zgadzał się z tym ujęciem myśli księcia o stosunkach międzynarodowych, któremu dałem wyraz w obszernym studium do nowego polskiego przekładu Essai sur la diplomatie $^{38}$. Napisał bowiem jasno, że poglądy Czartoryskiego były „ogniwem pośrednim między oświeceniowymi koncepcjami tzw. polskiej doktryny prawa narodów, traktującej narody jako podmioty uprawnień, które należy respektować, a różnymi wariantami romantycznej wizji uetycznienia lub chrystianizacji stosunków politycznych"39. W koncepcji tej upatrywał polski historyk idei rewolucyjny potencjał sprawy polskiej o dalekosiężnych konsekwencjach ${ }^{40}$. Ale - co istotne u polskiego księcia zwraca się ów „legitymizm narodów” przeciw systemowi „partykularnych racji stanu” - jak powie Walicki ${ }^{41}$.

Doniosłym zagadnieniem, któremu Walicki poświęcił dużo uwagi, był polski mesjanizm jako rodzaj utopii politycznej. Tomy artykułów: Filozofia a mesjanizm. Studia z dziejów filozofi i myśli społecznej romantyzmu polskiego (1970) oraz Między filozofia, religia i polityką. Studia o myśli polskiej epoki romantyzmu (1983) dały solidną porcję przemyśleń i odkrywczych konstatacji.

„Rozumiem mesjanizm - mówił pod koniec życia - nie jako szczególny związek narodu polskiego z Bogiem, ale jako pewną strukturę myślenia, która łączy się

37 A. Nowak, Republika, Imperium, Modernizacja: trzy wzory polskiego patriotyzmu, „Seminarium Polskiej Akademii Umiejętności" 6, 2011, s. 25-48; zob. też tenże, Republika i imperium: dwa patriotyzmy, w: Formuly patriotyzmu w Europie Wschodniej i Środkowej od nowożytności do wspótczesności, red. A. Nowak, A. Zięba, Kraków 2009, s. 77-102.

${ }^{38}$ Chodzi o: A.J. Czartoryski, Rozważania o dyplomacji, tłum. J.M. Kłoczowski, oprac. i studium: Reforma dyplomacji i legitymizm narodów M. Kornat, Kraków 2011.

${ }^{39}$ Cytuję recenzję mojego dorobku naukowego $\mathrm{w}$ postępowaniu o nadanie profesury nauk humanistycznych (w Instytucie Historii PAN) z 24 V 2014 r.

${ }^{40}$ Mocno podkreśla to Walicki w tomie swych studiów: Idea narodu w polskiej myśli oświeceniowej... Zob. też jego przemyślenia w szkicu Rewolucyjność kwestii polskiej $i$ wynikające stąd konsekwencje..., s. 170.

${ }^{41}$ A. Walicki, Mesjanistyczne koncepcje narodu i późniejsze losy tej tradycji..., s. 88 (Walicki jako przykład podaje właśnie Essai sur la diplomatie Adama Jerzego Czartoryskiego z 1830 r.). 
z pojęciem terrestrializacji eschatologii, czyli przeniesienia w nasz świat Królestwa Bożego, i z oczekiwaniem drugiego Mesjasza - niekoniecznie Jezusa Chrystusa" ${ }^{\text {"42 }}$.

Zajęcie się zagadnieniem mesjanizmu dało Walickiemu sposobność do znaczącej korekty ustaleń poczynionych przez Józefa Ujejskiego w jego syntezie mesjanizmu w Polsce, która pozostaje ciągle niezastąpiona. Sam powie już po latach: „Starałem się zawsze uściślić definicję Józefa Ujejskiego sformułowaną w klasycznej książce Dzieje polskiego mesjanizmu do powstania listopadowego włącznie. Wychodzi on od bliskiej mi koncepcji mesjanizmu: uważa, że paradygmatyczną formą mesjanizmu jest religijny mesjanizm. W jego definicji zawiera się oczekiwanie jakiejś wielkiej bliskiej przemiany, zbawienia na ziemi, poprzedzonego okresem katastrof”. Ale na tym kończy się zgodność. „Potem Ujejski to rozmywa. Mówi, że w Polsce mesjanizm jest właściwie od początku do końca narodowy i zaczyna to pojęcie tak bardzo rozszerzać, że mesjanistyczne stają się zupełnie świeckie koncepcje: Staszicowski panslawizm, Kołłątajowskie nadzieje pokładane w Napoleonie czy nadzieje pokładane w Słowiańszczyźnie przez Surowieckiego. Mesjanizm widzi więc tam, gdzie pojawia się myśl o jakimś szczególnym posłannictwie narodu polskiego. Robi się z niego pojęcie bez dna. Starałem się je z powrotem uściślić, ale widzę, że to workowate i bezkształtne pojęcie mesjanizmu zdobyło popularność. Używa się go wtedy, gdy chodzi o szczególną rolę narodu, nawet nie misję, tylko rolę"43. Oczywiście niezbędna jest świadomość różnych odmian mesjanizmu, o co upominał się Walicki $\mathrm{z}$ naciskiem ${ }^{44}$.

Przede wszystkim istnieje - jak twierdził słusznie Walicki - mesjanizm i misjonizm. Pojęcia te nie są tożsame. Ten pierwszy jest „terrestrializacją” eschatologicznych wizji, podczas gdy ów drugi to rozmaite koncepcje misji dziejowej, od których nie był wolny niemal żaden naród.

Bliski Walickiemu pod względem ideowym Wiktor Sukiennicki (prawnik i sowietolog) napisał: „Z reguły i poniekąd z zasady ustosunkowuję się raczej podejrzliwie do wszelkich koncepcji mesjanistyczno-mistycznych, wietrząc w nich częstą autoreklamę" ${ }^{5}$. Otóż to właśnie jest niezwykłe, że kierując się podobną orientacją światopoglądową, potrafił Walicki zdobyć się jednak na znaczną porcję empatii w studiowaniu tych koncepcji.

Niezwykle ważną cechą pisarstwa Walickiego pozostaje porównawcze ujmowanie idei oraz ich wzajemne oddziaływanie. Wspomnijmy tylko rozważania o Mickiewiczu

${ }^{42}$ Tak to sformułował w wywiadzie Mesjanizm nie na nasze czasy [cz. 1], [wywiad udzielony S. Dudzie, T. Jerzewskiemu i K. Ołdakowskiemu SI], „Przegląd Powszechny” 2010, nr 9, s. 10.

43 Tamże.

44 Tu najważniejsze pozostaje studium komparatystyczne, które dał A. Walicki w tomie: Między filozofią, religia i polityką. Studia o myśli polskiej epoki romantyzmu, Warszawa 1983, s. 8-44.

${ }^{45}$ List Wiktora Sukiennickiego do Czesława Miłosza, 12 I 1968 r., Instytut Polski i Muzeum Sikorskiego, Londyn, Kolekcja W. Sukiennickiego, sygn. 214. 
na the idei romantyzmu francuskiego ${ }^{46}$. Inny znamienny przykład to studium Rosyjski socjalizm Aleksandra Hercena jako odpowiedź na mesjanizm polski ${ }^{47}$.

Artykuł Polska myśl religijna od deizmu do mesjanizmu dał Walickiemu sposobność do dalekich od powszechnego przekonania konstatacji na temat roli katolicyzmu w myśli polskiej doby porozbiorowej. W jego przekonaniu „od oświecenia przynajmniej do rewolucji 1848 roku niemal cała polska myśl społeczna - przede wszystkim myśl Wielkiej Emigracji, ale nie tylko - rozwijała się w opozycji do Kościoła katolickiego. Mylne jest przekonanie, że Kościół reprezentował niezmiennie wartości narodowe oraz że był z tego powodu prześladowany przez władze carskie. W rzeczywistości w pierwszej połowie XIX wieku Aleksander I, a częściowo nawet Mikołaj I traktowali Kościół jako największego wroga rewolucji, a tym samym naturalnego sojusznika Świętego Przymierza"48. Szeroką panoramę przemian duchowych pierwszej porozbiorowej generacji Polaków kreślił Walicki w ważnym artykule Problem religii w ideologiach "Polski odradzajacej się”: od deizmu do mesjanizmu ${ }^{49}$.

Wiele uwagi poświęcił Walicki Adamowi Mickiewiczowi. O ideach zawartych w jego Prelekcjach paryskich traktował szeroko w książce Mesjanizm Adama Mickiewicza w perspektywie porównawczej (Warszawa 2006). Ukazał poetę jako myśliciela, który podejmuje uniwersalne problemy swojej epoki, a w swych poszukiwaniach nie jest odosobniony.

Utopia Mickiewicza zwraca się z całą mocą przeciw temu, co dzisiejszym językiem nazwiemy realizmem politycznym. W ujęciu Mickiewicza wiek XVIII „to epoka dyplomacji”, zdegenerowanej, zepsutej, niszczycielskiej - jak stwierdzi poeta w swych wykładach o literaturach słowiańskich ${ }^{50}$. Potępił w nich i samą zasadę równowagi sił jako rodzaj „nowoczesnej idolatrii”"51.

Walickiemu przyświecała zawsze myśl, aby romantyzm polski jako formację intelektualną konfrontować z tym, co twierdzili tacy jego krytycy jak Cyprian Norwid, Stanisław Brzozowski czy Roman Dmowski ${ }^{52}$. Wymowne jest z pewnością to zestawienie nazwisk.

To, co nazywamy polską filozofią narodową - znaczoną nazwiskami Augusta Cieszkowskiego, Karola Libelta i Bronisława Trentowskiego - znalazło w osobie Walickiego najbardziej sumiennego badacza.

46 A. Walicki, Mesjanizm Adama Mickiewicza w perspektywie porównawczej, Warszawa 2006.

47 Tenże, Polska, Rosja, marksizm... (2011), s. 129-164.

48 Sformułowanie z wywiadu Walickiego dla dodatku „Europa” do pisma „Dziennik.pl” z 5 XI 2007 (rozmowę prowadził Sławomir Sierakowski).

49 Tekst wszedł do tomu Walickiego: Mesjanizm Adama Mickiewicza..., s. 45-124.

${ }^{50}$ Wszystkie sformułowania z wykładu XI poety w Collège de France; zob. A. Mickiewicz, Dzieła wszystkie, t. 9: Literatura słowiańska, oprac. L. Płoszewski, Warszawa 1935, s. 164.

${ }^{51} \mathrm{O}$ ideach zawartych tych wykładach szeroko traktuje Walicki w tomie: Mesjanizm Adama Mickiewicza... Wziąć trzeba pod uwagę także jego uwagi w zbiorze studiów: Philosophy and Romantic Nationalism. The Case of Poland, Oxford 1982.

52 A. Walicki, Zniewolony umyst po latach..., s. 217. 
W 1972 r. doprowadził Walicki do skutku edycję pism Augusta Cieszkowskiego w tomie: Prolegomena do historiozofii. Bóg i palingeneza oraz inne pisma filozoficzne $z$ lat $1838-1842^{53}$. Podobnie doprowadził do wydania kluczowego dzieła Karola Libelta Samowładztwo rozumu i objawy filozofii słowiańskiej, w swoim opracowa$\mathrm{niu}^{54}$. Przygotował wreszcie tom pism Bronisława Trentowskiego Stosunek filozofii do cybernetyki oraz Wybór pism filozoficznych z lat 1842-1845 ${ }^{55}$. Wszystkie te edycje nie tyle opatrzył Walicki wstępami, co poprzedził studiami, a po zestawieniu tych tekstów w jedną całość z pewnością powstałaby osobna książka.

Rozważając poglądy Libelta - i w ogóle jego „filozofię słowiańską” - Walicki odkrywał przeciwstawienie konserwatywno-romantycznej koncepcji narodu i „oświeceniowej, racjonalistycznej idei uniwersalnego postępu ludzkości” ${ }^{56}$. Pisząc o Trentowskim i „podstawach filozofii uniwersalnej”, Walicki dał ocenę tego myśliciela jako jednego „z najbardziej niebezpiecznych przeciwników Kościoła”, który głosił, że „Bóg stwarza człowieka w niebie, człowiek zaś Boga na ziemi”" ${ }^{\text {. Tekst }}$ Walickiego Polityka i religia w koncepcjach filozoficznych Bronisława Trentowskiego przynosił konstatację o dużej oryginalności i antyromantyczny charakter jego poglądów historycznych ${ }^{58}$. Wreszcie, studiując pisma Cieszkowskiego, rozpatrywał je w „kontekstach intelektualnych” swojej epoki, a traktat o siedmiu prośbach modlitwy Ojcze nasz uważał za ,jedną z wielkich syntez polskiego romantyzmu”, która rozmija się jednak z ortodoksją katolicką ${ }^{59}$.

Last but not least - Walicki znacząco przyłożył ręki do odkrycia na nowo Stanisława Brzozowskiego, myśliciela doby polskiego modernizmu, który zajmuje dosyć osobliwe miejsce w polskiej myśli filozoficznej i politycznej doby porozbiorowej ${ }^{60}$. Powiedział o nim pod koniec życia: „Brzozowski należy do najbardziej konsekwentnych krytyków ewolucjonistycznego determinizmu, zdejmującego z ludzi odpowiedzialność za ich społeczny los. Jego epigenetyczna teoria historii rozbijała tezę o bezalternatywności procesu dziejowego, głoszoną

53 A. Cieszkowski, Prolegomena do historiozofii. Bóg i palingeneza oraz inne pisma filozoficzne z lat 1838-1842, oprac. i wstęp A. Walicki, Warszawa 1972.

${ }^{54}$ K. Libelt, Samowładztwo rozumu i objawy filozofii słowiańskiej, Warszawa 1967.

${ }_{55}$ B. Trentowski, Stosunek filozofii do cybernetyki oraz Wybór pism filozoficznych z lat 1842-1845, wstęp i koment. A. Walicki, Warszawa 1974.

${ }^{56}$ A. Walicki, Samowładztwo rozumu i objawy filozofii słowiańskiej, w: K. Libelt, Samowładztwo rozumu i objawy filozofii słowiańskiej, wyd. 2, oprac. i wstęp. A. Walicki, Warszawa 2014, s. XXIV.

${ }^{57}$ B. Trentowski, Podstawy filozofii uniwersalnej; Wstęp do nauki o naturze, z oryg. niem. tłum. M. Żułkoś-Rozmaryn, przyp. J. Garewicz, wstęp A. Walicki, Warszawa 1978, s. XXXIV (cytuję wprowadzenie Walickiego).

58 A. Walicki, Polityka i religia $w$ koncepcjach filozoficznych Bronisława Trentowskiego, w: B. Trentowski, Wybór pism filozoficznych z lat 1842-1845, wyd. 2, Warszawa 2014, s. XLIX.

59 Tenże, Pisma filozoficzne cieszkowskiego z lat 1838-1842 w kontekstach intelektualnych epoki, w: A. Cieszkowski, dz. cyt., s. XLVII.

60 Doprowadził do pierwszej w PRL sesji o Brzozowskim 17-19 I 1972 r., której plonem stał się tom Wokół myśli Stanisława Brzozowskiego, red. A. Walicki, R. Zimand, Kraków 1974. 
przez dogmatycznych marksistów i przejętą od nich przez wolnorynkowych "neoliberalistów«"61. Nic dodać, nic ująć.

Andrzej Walicki nie stworzył książki o Romanie Dmowskim, ale zajmował się jego myślą polityczną, poczynając od 1999 r., kiedy ogłosił drukiem artykuł The Troubling Legacy of Roman Dmowski ${ }^{62}$. Pisma przywódcy Narodowej Demokracji poddał uważnej lekturze. Widział w jego koncepcjach bardzo znaczący zwrot ku realizmowi politycznemu, ale i niebezpieczne tendencje.

Podkreślał, że już w broszurze Nasz patriotyzm z 1893 r. przyszły przywódca Narodowej Demokracji próbował stworzyć definicję Polaka. Notował istnienie Polaków uświadomionych, a tym samym rzeczywistych członków wspólnoty wyobrażonej ${ }^{63}$. Ale znajdywał i „Polaków nominalnych” - a więc tylko mieszkańców ziem polskich, których Polakami dopiero trzeba uczynić. Walicki dostrzegał w tej diagnozie wyraźną „zapowiedź niebezpiecznego ekskluzywizmu”. Dmowskiego „nowoczesny naród” to wspólnota ukształtowana wokół idei „jednomyślności w sprawach zasadniczych”. Orientacja taka to przesłanka późniejszej praktyki „ekskomunikowania” ze wspólnoty narodowej myślących inaczej, wyznających inny system wartości. Postępowanie takie przyniosło modelowy przejaw „nacjonalizmu ekskluzywnego" 64

Trudno nie podkreślić, że Walicki występował w obronie pojęcia nacjonalizm, które w polskim dyskursie publicznym ma od dawna mniejsze lub większe zabarwienie pejoratywne. Podkreślał, iż w jego anglosaskim rozumieniu tak nie jest. Stawiał sobie i pytanie o to, czy nacjonalizm może być liberalny ${ }^{65}$. $\mathrm{Z}$ całą wreszcie pewnością utrzymywał, że naród jako zbiorowość to najbardziej trwała wspólnota ludzka, jaką wytworzyła historia. Winna jednak być pluralistyczna i „wieloświatopoglądowa”.

\section{Marksizm i bolszewizm}

Andrzej Walicki - podkreślmy to - nigdy nie był „wierzącym” marksistą. Owszem, $\mathrm{w}$ dobie stalinowskiego porządku w kraju zmagał się z doświadczeniem „nowej wiary”. Przeżywał „od wewnątrz” to, co Miłosz nazwał ketmanem. Ale

${ }^{61}$ Cytat z wywiadu Walickiego dla Michała Sutowskiego - włączony do książki Brzozowski. Przewodnik Krytyki Politycznej, wydanej przez Wydawnictwo Krytyki Politycznej (Warszawa 2011).

62 „East European Politics and Societies” 1, 1999, s. 12-46.

${ }^{63}$ Świadomie używam tu pojęcia zapożyczonego od Benedicta Andersona (tenże, Imagined Communities. Reflections on the Origin and Spread of Nationalism, London 1983; wyd. pol.: Wspólnoty wyobrażone. Rozważania o źródłach i rozprzestrzenianiu się nacjonalizmu, tłum. S. Amsterdamski, Kraków 1997).

${ }^{64}$ A. Walicki, Naród, nacjonalizm, patriotyzm, wstęp A. Mencwel, Kraków 2009 (Kultura i Myśl Polska. Prace Wybrane Andrzeja Walickiego, 1), s. 498-499 n.

${ }^{65}$ Do tych spraw tom studiów Walickiego, które sam zebrał: Naród, nacjonalizm, patriotyzm... Pojęcie „liberalny nacjonalizm” pojawiło się np. w pracy pióra Yaela Tamira: Liberal Nationalism, Princeton 1993. 
marksizm jako fenomen życia umysłowego i politycznego podejmował badawczo nie jako rozczarowany wyznawca, tylko historyk idei, który najpierw usiłuje zrozumieć to, co chce objaśniać.

Marksizm był dla Walickiego ideologią zrodzoną na Zachodzie, „wyposażoną w autorytet nauki i cieszącą się reputacją ostatniego słowa ogólnoludzkiego postępu"66. Pierwsze prace z tej problematyki stworzył w drugiej połowie lat 70. Podejmował zagadnienia marksizmu, wychodząc z przeświadczenia, że marksizm należy zrozumieć. Że są różne odmiany marksizmu. Wreszcie - że marksizm-leninizm w wersji urzędowej nie jest oczywiście jedyną wersją filozofii marksistowskiej. Z tym to przekonaniem Walicki stworzył i ogłosił drukiem napisaną w latach 70. monografię myśli Stanisława Brzozowskiego, odkrywając na nowo tę postać, wówczas dość zapomnianą ${ }^{67}$.

W 1983 r. ogłosił Walicki ważny tom swoich studiów: Polska, Rosja, marksizm. Studia $z$ dziejów marksizmu i jego recepcji.

Centralna w marksizmie jest idea wyzwolenia człowieka - nie tyle jednostki, ile człowieka jako gatunku, co Walicki zawsze podkreślał. W swoich Głównych nurtach marksizmu Leszek Kołakowski napisał: „Rzecz w tym, że Marks rzeczywiście i konsekwentnie wierzył w to, iż społeczeństwo ludzkie nie może być »wyzwolone« nie osiągając jedności. Tymczasem prócz despotyzmu nie ma techniki prowadzącej do jedności społecznej; nie ma innego sposobu zniesienia napięcia między społeczeństwem cywilnym i politycznym, aniżeli zniesienie społeczeństwa cywilnego; nie ma innych środków na usunięcie konfliktów między jednostką i »całością", prócz zniszczenia jednostki; nie ma innej drogi ku »wyższej«, "pozytywnej« wolności - w odróżnieniu od wolności »negatywnej«, »burżuazyjnej« - aniżeli likwidacja tej ostatniej. A jeśli by było prawdą, że całą historię ludzką ujmować należy w kategoriach klasowych, że wszystkie wartości, wszystkie instytucje polityczne i prawne, idee, normy moralne, wierzenia religijne i filozoficzne, twórczość artystyczna itd., są "niczym innym, jak« narzędziami w służbie "rzeczywistych «, czyli klasowych, interesów (a są liczne fragmenty w pismach Marksa na rzecz tej doktryny), to prawdą jest również, że nowe społeczeństwo musi zacząć się od gwałtownego przerwania ciągłości kulturalnej ze starym"68. Interpretacja marksowskiej idei wolności u Walickiego nie sprzeciwia się temu wywodowi. Książką Marxism and the Leap to the Kingdom of Freedom ogłoszoną drukiem w Kalifornii (Stanford University) w 1995 r., a rok później w języku polskim - dawał raczej nowe uzasadnienie tych konstatacji. Ale też szedł dalej.

${ }^{66}$ A. Walicki, Marksizm i skok do królestwa wolności. Dzieje komunistycznej utopii, Warszawa 1996, s. 17.

${ }^{67}$ Tenże, Stanisław Brzozowski - drogi myśli, Warszawa 1977.

${ }^{68}$ L. Kołakowski, Marksistowskie korzenie stalinizmu, w: tenże, Czy diabeł może być zbawiony i 27 innych kazań, Londyn 1984, s. 257. 
Między Kołakowskim a Walickim występuje jedno zasadniczo odmienne podejście do Marksa. Autor Głównych nurtów marksizmu nie poświęcił uwagi marksowskiej wizji przyszłości - przyszłego społeczeństwa, nawiązując tu do tych interpretacji, które sugerowały nawet jej brak. A to „pozwalało zapytać wprost o losy najważniejszej próby realizacji komunistycznej utopii" ${ }^{69}$. Praca Marksizm i skok do królestwa wolności. Dzieje komunistycznej utopii daje w tej sprawie cenne naświetlenia. W ten sposób Walicki przyniósł nam szczególnie ważną interpretację systemu sowieckiego. U jej podstaw tkwi pogląd, że doświadczenie sowieckie, czyli w konsekwencji dzieje określonej aplikacji praktycznej marksizmu, są utopijną projekcją, mającą za podstawę fundamentalną koncepcję wolności. Ta wolność, niedostępna w ustroju liberalno-rynkowym, miała przynieść alternatywę $\mathrm{w}$ postaci ostatecznego spełnienia ideału. Tym samym śladem poszedł w swej syntezie Leszek Kołakowski, dając pogląd o katastrofie marksistowskiego projektu definitywnego wyzwolenia człowieka i przekreślenia dehumanizującej alienacji. Tak zatem czy inaczej, dwie przywołane wizje zbiegają się w jednym dogłębnym podobieństwie. W kwestii totalitaryzmu Walicki powtarzał te myśli wielokrotnie. Najobszerniej wypowiedział się oczywiście książką Marksizm i skok do królestwa wolności. Na ten temat zabierał też głos zwłaszcza w licznych esejach, wywiadach, artykułach i rozważaniach drukowanych w ostatnich latach swego życia.

Pytania o to, czy marksizm jako system filozoficzny ponosi odpowiedzialność za totalitaryzm sowiecki, który naznaczył XX wiek - nie da się ominąć. Oczywiście stawiał je sobie Walicki.

Książka Marksizm i skok do królestwa wolności była próbą syntezy wielkiego problemu. Przynosiła rozległą panoramę dziejów marksizmu jako filozofii wolności, ale wolności rozumianej w radykalnej sprzeczności z tradycją liberalną, która wolność jednostki rozumie jako „wolność od”. Jest to właśnie wolność negatywna $\mathrm{w}$ rozumieniu Isaiah Berlina ${ }^{70}$. Książka Walickiego nie jest historią marksizmu, jaką dał Kołakowski w Główny nurtach marksizmu ${ }^{71}$. Ale śledzi „losy komunistycznego ideału wyzwolenia ludzkości”, od początków (a więc od Manifestu komunistycznego) po krach idei komunistycznej w drugiej połowie XX w. ${ }^{72}$

Znamienne jest z pewnością to ukazanie myśli „młodego Marksa”, które w swoich Głównych nurtach marksizmu przeciwstawił Kołakowski jego pismom późniejszym, starając się w tych pierwszych dostrzec przesłanie wolnościowe. Co istotne,

${ }^{69}$ Tak ujął to Walicki w wywiadzie udzielonym Januszowi Dobieszewskiemu i Pawłowi Kozłowskiemu (Moje sprawy z Marksem i marksizmem): P. Kozłowski, Spotkania z Andrzejem Walickim, Warszawa 2021, s. 260.

70 Tu tom esejów I. Berlina, Dwie koncepcje wolności i inne eseje, wybór i oprac. J. Jedlicki, tłum. H. Bartoszewicz i in., posł. P. Śpiewak, Warszawa 1991.

${ }^{71}$ L. Kołakowski, Główne nurty marksizmu. Powstanie, rozwój, rozkład, Londyn 1988 (wyd. 1, t. 1-3, Paryż 1976-1978).

72 A. Walicki, Marksizm i skok do królestwa wolności..., s. 373. 
Walicki zasadniczo nie poszedł tą drogą ${ }^{73}$. Za centralną kategorię pojęciową u Marksa uznał koncepcję alienacji. Obaj polscy historycy idei godzili się z tym, że to klucz do zrozumienia idei niemieckiego filozofa. Godzili się też i na to, aby uznać, że bolszewizm to jedna z prawomocnych kontynuacji marksizmu. W tej sprawie nie występowała żadna rozbieżność między Walickim a Kołakowskim. „Aby uzasadnić całkowitą eliminację wolności indywidualnej i grupowej, partia bolszewicka musiała powoływać się także na inne wątki marksistowskiej teorii społecznego wyzwolenia. [...] marksizm-leninizm był w samej rzeczy prawomocnym rozwinięciem pewnych fundamentalnych idei klasycznego marksizmu. Jak wszystkie wielkie i złożone systemy ideologiczne marksizm miał oczywiście wiele twarzy i mógł być poddawany interpretacjom bardzo różnym, zależnym od historycznego usytuowania interpretatorów"74.

Jednym z najbardziej przekonujących wniosków Walickiego jest przeświadczenie, iż ta właśnie filozofia wolności stanowi o „totalitarnym potencjale” marksizmu, a zarazem legitymację totalitarnych praktyk (użycia na wielką skalę przemocy, zastosowania inżynierii społecznej, masowej indoktrynacji i mobilizacji społecznej w imię utopijnego celu). Stanowisko to różni się - i to zasadniczo - od dominującego kierunku w zachodnich interpretacjach marksizmu i jego dziejowej roli ${ }^{75}$.

Synteza Walickiego Marksizm i skok do królestwa wolności. Dzieje komunistycznej utopii obejmuje oczywiście dzieje marksizmu sowieckiego czy też tego, co za marksizm w ZSRR uważano ${ }^{76}$. A więc oczywiście i marksizm stalinowski, skodyfikowany na swój sposób jako doktryna legitymizująca totalitarne państwo.

„Jak wiadomo przed I wojną światową ideologia marksistowska cieszyła się największymi wpływami w dwóch krajach: w Niemczech i w Rosji. Tylko w Rosji wszakże doprowadziło to do powstania pretotalitarnej partii rewolucyjnej i do zbudowania na gruzach monarchii totalitarnego państwa" - pisał Walicki ${ }^{77}$. Marksizm był ideologią zachodnią, do Rosji importowaną. W Rosji jednak dał podwaliny państwa totalitarnego. Co do tych dwóch konstatacji zgadzają się wszyscy. Ale spór na tym się nie kończy. Czy totalitarny ruch, jakim była partia bolszewicka, wyrósł wskutek istnienia specyficznych uwarunkowań historycznych w Rosji, czy też był konsekwencją przyjęcia ideologicznych dogmatów marksizmu? Fundamentalny to dylemat historiografii bolszewizmu.

Walicki zajął w tej sprawie stanowisko. Stwierdził jednoznacznie: „Tak czy inaczej odrzucić należy pogląd, że socjaldemokraci niemieccy dochowali wierności

73 Tu bardzo ważny jest list Walickiego do Kołakowskiego z 27 IV 1993 r., zob. L. Kołakowski, A. Walicki, Listy 1957-2007, podał do druku A. Walicki, oprac. H. Citko, Warszawa 2018, s. 191-193.

${ }_{74}$ A. Walicki, Marksizm i skok do królestwa wolności..., s. 20.

75 Swoje stanowisko wobec Marksa i marksizmu naświetlił Walicki we wspomnianym długim wywiadzie: Moje sprawy z Marksem i marksizmem..., s. 229-270.

76 A. Walicki, Marksizm i skok do królestwa wolności..., s. 20.

77 Tamże. 
prawdziwemu marksizmowi, podczas gdy bolszewizm wniósł do marksizmu elementy obce, poddał go swoistej "rusyfikacji «" 78 .

Nawet przy konsensusie, że marksizm był intelektualnym produktem Zachodu, a nie owocem rozwoju myśli rosyjskiej, powstają jednak znaki zapytania. W Rosji powstał wszak system ustrojowy, który był realizacją utopii społeczeństwa komunistycznego, tj. harmonijnej syntezy antynomicznych wartości, jakimi są wolność i równość. Na glebie cywilizacyjnej Zachodu natomiast spuścizna marksowska podlegała wielu interpretacjom, została poddana selektywnej asymilacji przez kierunek socjaldemokratyczny i często podlegała różnorakiej rewizji. Jak objaśnić ów paradoks? Czy przyczyn tego stanu rzeczy nie należy poszukiwać w historii rosyjskiego despotyzmu, w mentalności ukształtowanej na gruncie autokracji rosyjskiej? Czy nie trzeba w tym celu sięgnąć do argumentów wskazujących na specyfikę rosyjskiej duchowości?

Trudno, aby na tym miejscu nie wybrzmiało, że Walicki rehabilitował Rosję carską, mocno sprzeciwiając się teorii kontynuacji. Pisał: „często zadawałem sobie pytanie, w jakiej mierze Rosja Radziecka, a w szczególności stalinowska, jest kontynuacją przedrewolucyjnej Rosji, w jakie mierze tradycja rosyjska, zwłaszcza zaś tradycja rewolucyjnej rosyjskiej inteligencji, przyczyniła się do powstania w XX wieku nowej, iście monstrualnej formy azjatyckiego despotyzmu. Tezę o kontynuacji prostej, bezpośredniej, rozwiniętą $\mathrm{w}$ wielotomowym dziele Jana Kucharzewskiego Od białego caratu do czerwonego, z punktu odrzucałem: istotę stalinizmu upatrywałem przecież w zniewoleniu umysłów, w dokonywanej przemocą uniformizacji życia duchowego, a czegoś takiego nie było w Rosji dziewiętnastowiecznej, najlepiej mi znanej"79.

W książce będącej hołdem złożonym Czesławowi Miłoszowi (Zniewolony umyst po latach) Walicki stwierdzał, że „nawet w czasach Mikołaja I, określanych jako apogeum reakcji, władza polityczna miała zakres wąski, nie przenikała we wszystkie dziedziny życia społecznego; myśl o upaństwowieniu gospodarki, a cóż dopiero kultury, czyli myśl o przekształceniu całej ludności w kierowanych przez władzę czynowników była jej najzupełniej obca" ${ }^{\prime 80}$. Między Rosją przedrewolucyjną a tą powstałą w wyniku rewolucji bolszewickiej powstała przepaść. Stanowisko Walickiego pozostaje więc bezwzględnie zwrócone przeciw koncepcjom Kucharzewskiego czy Richarda Pipesa. Dodajmy jeszcze, że tak argumentował zwłaszcza Aleksander Sołżenicyn ${ }^{81}$.

„Interpretacja gigantycznego eksperymentu komunistycznego w Rosji jako rezultatu swoiście rosyjskiej kultury politycznej jest uchyleniem się od odpowiedzi na pytanie najbardziej zasadnicze: czy Rosja stworzyłaby totalitaryzm - i to totalitaryzm

78 Tamże.

79 A. Walicki, Zniewolony umysł po latach..., s. 114.

80 Tamże.

81 Mam na myśli przede wszystkim książkę Sierpień czternastego, ogłoszoną na emigracji w 1972 r. 
najbardziej konsekwentny, bo komunistyczny - bez poddania się dominującemu wpływowi ideologii komunistycznej stworzonej na Zachodzie, wyposażonej w autorytet nauki i cieszącej się reputacją ostatniego słowa ogólnoludzkiego postępu?"\$2. Na pytanie to odpowiadał Walicki stwierdzeniem, że nie możemy starać się o „»uniewinnienie " marksizmu”, albowiem tym właśnie byłoby usiłowanie „wyjaśnienia komunizmu przez czynniki zewnętrzne wobec marksizmu i nieobecne na Zachodzie" ${ }^{33}$. Warto - jak sądzę - myśl tę podkreślić, gdyż nie przebiła się ona do publicznego dyskursu o przeszłości.

Walicki nie wywodził korzeni sowieckiego totalitaryzmu z rosyjskiego dziedzictwa autokracji. Tkwiący w marksizmie ideał wolności absolutnej i pogodzonej z równością powszechną dał pierwszy w swej historii tak straszliwy owoc w postaci sowieckiego eksperymentu. Ale i on - podkreślmy to - zmuszony był przyznać, że cechą specyficzną narodnictwa, która charakteryzuje również i umysłowość Lenina, była „głęboko zakorzeniona nieufność wobec praworządności i demokracji politycznej”84.

Czy jednak o wytworzeniu totalitarnego systemu przesądził przypadek? Odpowiadając na to pytanie, Walicki podnosił, że chociaż „»pewien zwarty nurt historiografii « widzi w tym dowód swoistego "pokrewieństwa $\mathrm{z}$ wyboru« między totalitaryzmem a rosyjską kulturą i tradycją narodową, [to] wydaje się jednak, że większą rolę odegrały tu czynniki zewnętrzne, związane z klęską wojenną, a więc niewytłumaczalne w kategoriach determinizmu kulturowego" ${ }^{\prime 3}$. Zbieżność tych wyjaśnień polskiego profesora oraz rosyjskich historyków - zwłaszcza Michaiła Hellera - pozostaje widoczna ${ }^{86}$.

Jaką rolę u źródeł bolszewizmu i systemu sowieckiego spełniło typowo rosyjskie dziedzictwo autokracji i despotyzmu? - to inne wielkie pytanie towarzyszące Walickiemu od dawna. Nota bene, tak kwestia roli marksizmu w wygenerowaniu totalitarnej rzeczywistości, jak i znaczenia dziedzictwa autokracji rosyjskiej w wytworzeniu systemu leninowsko-stalinowskiego, to sprawy przez historyków idei rozważane już wiele razy, a rozległa historiografia marksizmu wciąż musi do nich na nowo powracać, jeśli chce objaśnić triumf bolszewików w październiku $1917 \mathrm{r}$.

Wobec dzieła Jana Kucharzewskiego Od caratu białego do czerwonego wypowiedział się Walicki niezwykle stanowczo ${ }^{87}$. Sposobności dostarczyła moja praca o początkach polskiej myśli sowietologicznej: Bolszewizm, totalitaryzm,

82 A. Walicki, Marksizm i skok do królestwa wolności..., s. 17.

83 Tamże.

${ }^{84}$ A. Walicki, Od narodnictwa do leninizmu, w: tenże, Idea wolności u myślicieli rosyjskich..., s. 265.

85 Tenże, Marksizm i skok do królestwa wolności..., s. 17.

${ }^{86}$ Chodzi tu zwłaszcza o książkę Historia imperium rosyjskiego (1997), tłum. E. Melech, T. Kaczmarek, Warszawa 1999.

87 „Przegląd Polityczny” 2006, nr 76, s. 139-152 (w związku z moją książką: Bolszewizm, totalitaryzm, rewolucja, Rosja. Początki sowietologii i studiów nad systemami totalitarnymi w Polsce (1918-1939), t. 1-2, Kraków 2003-2004, obok innych jej recenzji pióra A. Nowaka, K. Pomiana). 
rewolucja, Rosja. Początki sowietologii i studiów nad systemami totalitarnymi $w$ Polsce (1918-1939). Pisząc z niej recenzję, podkreślił, iż Martin Malia, „na podstawie anglojęzycznego skrótu dzieła Kucharzewskiego, uznał polskiego historyka za skrajnego przedstawiciela »esencjalizmu « w interpretacji Rosji - rozumiejąc przez to tezę o esencjalnej niezmienności Rosji oraz jej całkowitej odrębności i obcości wobec Europy"88. Przedstawicielem tego „esencjalizmu” był dla Malii Richard Pipes, którego Rewolucja rosyjska - „na co sam wskazał w swych Memoirs of a non-Belonger - uznana została w Europie za manifestację rusofobii", lecz jest on „w porównaniu z Kucharzewskim szczytem interpretacyjnej ostrożności! Kucharzewski bowiem - nazwijmy rzecz po imieniu - uznał Rosję nie tylko za esencjalnie odrębną i obcą, ale również za kraj »nienormalny«, za historyczną anomalię (różniąc się tym od np. Spenglera, który uznawał »esencjalną odrębność«, ale odrzucał pojęcie »nienormalności«). Innymi słowy: teoria »esencjalizmu« jest dziś mało popularna, nikt nie odważa się głosić jej otwarcie, ale poglądy Kucharzewskiego są, niestety, karykaturą tej teorii. Jeśli zatem w tezie o nieredukowalnej odrębności jest coś słusznego, to obrona owego "ziarna słuszności« musi zacząc się od zdystansowania się od tej karykatury”. Summa summarum, Walicki utrzymywał, że „dzieło Kucharzewskiego jest właściwie siedmiotomowym aktem oskarżenia, całe jego rozdziały składają się ze zdań negatywnie oceniających, co jest dokładnym przeciwieństwem metody badawczej Sukiennickiego i Świaniewicza. Nie przeczę, że jest w nim wiele trafnych obserwacji, ale sąsiadują one $\mathrm{z}$ interpretacjami skrajnie tendencyjnymi" ${ }^{\prime 9}$.

W mojej rozprawie Bolszewizm, totalitaryzm, rewolucja, Rosja upomniałem się o Kucharzewskiego, umiarkowanie broniąc jego koncepcji. Przypomniałem, że dowodził on przede wszystkim tego, iż „carat to nie tylko system mechanicznego ujarzmienia, to jeszcze system umysłowo-moralny, to nie tylko siła materialna, lecz i wierzenia, przesądy, nałogi, tradycje, myśli i uczucia milionowych mas" ${ }^{\prime 90}$. I na tym polegał fenomen autokracji rosyjskiej. Pisałem, że stawiał „wykrywanie w przeszłości elementów przyszłej rewolucji, śledzenie jej genezy, wskazywanie jej zwiastunów". Wspomniałem wreszcie - podążając za Wojciechem Karpińskim - że książka Kucharzewskiego była w istocie studium o duchu bezprawia, bo „jego celem było śledzenie form zdegenerowanych i mechanizmów degeneracji. Interesował go proces historyczny: w przeszłości szukał źródeł ciemnych elementów widocznych w dzisiejszym życiu społecznym"91. Walicki docenił te wysiłki

${ }^{88}$ M. Malia, Under the Western Eyes. From the Bronze Horseman to the Lenin Mausoleum, Harvard 1999, s. 3-14. O Kucharzewskim zob. uwagi Malii na s. 437-438.

89 „Przegląd Polityczny” 2006, nr 76, s. 130.

90 J. Kucharzewski, Od białego caratu do czerwonego, t. 1: Epoka Mikołajowska, Warszawa 1923, s. 131 (wszystkie cytaty za tym wydaniem).

91 W. Karpiński (pod pseud. K. Opaliński), O duchu bezprawia, „Kultura” 1974, nr 12(327), s. 9-23. 
w swojej recenzji mojej pracy (jako rozprawy habilitacyjnej), ale stwierdził, iż „Polacy powinni [...] starać się o przezwyciężenie stereotypu "polskiej rusofobii", obraca się on bowiem przeciwko nam samym. Marek Kornat rozumie to, stara się więc złagodzić skrajną rusofobię Kucharzewskiego. Mimo to jednak uważa autora Od białego caratu do czerwonego za »sowietologa« - co sugeruje, że można być sowietologiem tylko na podstawie bardzo określonych poglądów na istotę »rosyjskości«. Sądzę, że jest to błędem, wynikającym ze swoistego »renesansu « idei Kucharzewskiego w III RP"92.

Jak widzimy, Walicki zwracał się bardzo wyraźnie przeciwko koncepcjom, które wyraża teoria kontynuacji ${ }^{93}$. Ale nie jest tak, że rosyjskie realia historyczne nie oddziaływały na recepcję marksizmu w tym kraju. W posłowiu do ogłoszonej, a napisanej w 1958 r., wspomnianej już pracy Od narodnictwa do leninizmu, Walicki przyznał, że już wówczas, tj. w czasie, gdy pisał to studium, „specyficznie rosyjska geneza bolszewizmu" była dla niego bardzo widoczna. Podkreślił jednak zaraz z naciskiem, że - zwłaszcza $\mathrm{w}$ świetle swych późniejszych przemyśleń umocnił się w wyznawanej tezie, wedle której bolszewizm „mimo wszystkich cech specyficznie rosyjskich wyrastał jednak z głównego pnia komunizmu europejskiego i dzięki temu właśnie wywierać mógł fascynujący wpływ na tak wielu intelektualistów Zachodu"94. Pisząc swe studium Od narodnictwa do leninizmu, Walicki nie miał żadnych wątpliwości, że w umysłowości Lenina „cechą specyficznie narodnicką” była „głęboko zakorzeniona nieufność wobec praworządności i demokracji politycznej”95. Można dodać, że międzywojenny sowietolog polski Stanisław Swianiewicz, profesor Uniwersytetu w Wilnie i Instytutu Naukowo-Badawczego Europy Wschodniej, w studium o myśli politycznej Lenina z 1930 r. pt. Lenin jako ekonomista mocno zaakcentował ten właśnie poglą $\mathrm{d}^{96}$.

\section{Fenomen totalitaryzmu}

Zainteresowanie Andrzeja Walickiego fenomenem totalitaryzmu wyrastało oczywiście z jego studiów nad marksizmem, studiów pogłębionych, samodzielnych i wieloletnich. Podjęcie przez niego fenomenu totalitaryzmu było w jakiejś mierze kontynuacją studiów nad marksizmem - podsumowanych syntezą Marksizm i skok do królestwa wolności.

92 „Przegląd Polityczny” 2006, nr 76, s. 130.

93 Jej postacią emblematyczną pozostaje na Zachodzie Richard Pipes za sprawą książki Russia under Old Regime, New York 1974 (wyd. pol.: Rosja carów, tłum. J. Bratkiewicz, wstęp i oprac. P.P. Wieczorkiewicz, Warszawa 1990).

94 A. Walicki, Posłowie, w: tenże, Idea wolności u myślicieli rosyjskich..., s. 303.

95 Tenże, Od narodnictwa do leninizmu..., s. 265.

96 Mimo takiego, a nie innego tytułu była to $\mathrm{w}$ istocie rozprawa o myśli politycznej wodza bolszewików. 
Teoria totalitaryzmu powstała jako idea we Włoszech pod rządami faszystów. Zrobiła, jak wiadomo, wielką karierę w zachodnim życiu umysłowym doby zimnej wojny. Klasyczny charakter książek The Origins of Totalitarianism Hannah Arendt (1951) czy też Carla Friedricha i Zbigniewa Brzezińskiego Totalitarian Autocracy and Dictatorship (1956) przyczynił się do pewnego skodyfikowania tez zwolenników tej koncepcji. Po 1956 r. - w atmosferze przełomowego XX Zjazdu KPZR w Moskwie - powstała silna tendencja do negacji teorii totalitaryzmu, co dało początek rewizjonistycznemu kierunkowi w historiografii zachodniej jako koncepcji par excellence politycznej, zimnowojennej, stygmatyzującej państwo sowieckie, które przecież nie było tym samym co III Rzesza. Nie jest $\mathrm{z}$ pewnością przypadkowe to, że niemiecka powojenna „polityka historyczna” (Geschichtspolitik) podchodziła $\mathrm{z}$ dystansem do teorii totalitaryzmu, aby nie osłabiać tezy o wyjątkowości zbrodniczego reżimu Hitlera poprzez zabiegi porównawcze obydwu dyktatur: niemieckiej i sowieckiej.

Przed historykiem idei, które podejmuje w swych studiach problematykę dwudziestowiecznych ustrojów „nowego typu”, otwierają się trzy możliwe stanowiska w przedmiocie teorii totalitaryzmu: (1) jej całkowite odrzucenie jako poznawczo wątpliwej i niewydajnej, (2) akceptacja wraz z koniecznością sprecyzowania, który model spośród licznych definicji totalitaryzmu przyjmuje, (3) przyjęcie pojęcia totalitaryzmu i zarazem podjęcie próby takiej jego modyfikacji, aby uwzględnić te doświadczenia, jakie rozkład „realnego socjalizmu” wniósł do historii najnowszej. Andrzej Walicki opowiedział się za tą trzecią opcją. W jego ujęciu termin „totalitaryzm" jest użyteczny, mimo swojego pozanaukowego i ideologicznego kontekstu, czego Walicki jest świadom. Od początku też autor Zniewolonego umysłu po latach poszukiwał wyjaśnienia specyfiki tego fenomenu historycznego i odpowiedzi na wiele pytań niezmiernie ważnych, dość lekceważonych jednak - można odnieść takie wrażenie - przez historyków polskich. Czym wyróżnia się fenomen państwa totalitarnego na tle innych dyktatur "nowego typu” w XX stuleciu? Co zadecydowało o kryzysie i rozkładzie totalitarnego komunizmu? Czy mówienie o totalitaryzmie w perspektywie polskiej - tj. o totalitarnym charakterze PRL - ma sens?

I tak oto w historiografii idei totalitaryzm interpretować można jako formę „ideokracji” lub jako rezultat „historycznego rozwoju” "97. Stanowisko Walickiego jest jednoznaczne. Jego zdaniem sowiecka wersja porządku totalitarnego to przede wszystkim „ideokracja”, rządy utopii. Ma to być zatem radykalna utopia, której sens sprowadzałby się do pomysłu obdarowania społeczności ludzkiej „wolnością rzeczywistą", tzn. inną niż liberalna. Tak więc jest to fenomen usytuowany w skali powszechno-dziejowej, niedający się zamknąć w granicach Rosji z jej rodzimą tradycją historyczną. W ten sposób Walicki porusza problem

97 Interesujące jest najnowsze podsumowanie tej dyskusji - a dał ją Abbott Gleason, Totalitarianism, Oxford 1995, s. 121-142. 
kluczowy, wciąż podstawowy z punktu widzenia wymagań współczesnej historiografii ustrojów totalitarnych.

Walicki rozróżniał trzy odmienne zastosowania terminu „totalitaryzm” do realiów historycznych. Wyodrębniał trzy odmienne modele, których utożsamiać nie wolno. Czymś innym jest (1) „totalitarny potencjał pewnych idei”, czymś innym (2) „totalitarny charakter pewnych ruchów rewolucyjnych” i czymś jeszcze innym (3) „totalitarny charakter państwa”.

Główne nurty marksizmu oraz Marksizm i skok do królestwa wolności nie pozostawiają wątpliwości co do stanowiska ich autorów. Rosja nie ma - w tej optyce „praw autorskich" na totalitaryzm. System totalitarny stanowi urzeczywistnienie wizji świata, który cechuje ideokratyczna władza i "gospodarka bezrynkowa”.

Andrzej Walicki nie miał wątpliwości co do tego, że najpierw zaistniał „projekt komunistyczny" (jak to nazywał), a potem nastąpiła próba jego realizacji - z wszystkimi tego konsekwencjami. Przekonanie to wyraził najmocniej w artykule Rewolucja Październikowa jako projekt komunistyczny ${ }^{98}$. Kluczowe sformułowanie „projekt komunistyczny" wprowadził też do tytułu jednej ze swych ostatnich książek ${ }^{99}$.

Wiele przemyśleń pozostawił Walicki w sprawie stalinowskiej wersji bolszewizmu i w ogóle fenomenu rządów Stalina.

Polemizując z poglądami Roberta Tuckera, amerykańskiego biografa Stalina, autora książki Stalin in Power. The Revolution from Above 1928-1941, Walicki pisał, iż argumenty rzeczników tezy, jakoby Stalin zerwał z dziedzictwem Lenina, nie wytrzymują krytyki ${ }^{100}$. Nie ma podstaw, twierdził polski historyk idei, aby „odcinać stalinizm od całej poprzedniej tradycji bolszewickiej”.

Siłą totalitaryzmu nie jest taka czy inna „substancja doktrynalna” ideologii, na którą władza totalitarna się powołuje i z której czerpie legitymizację. Liczy się nade wszystko mit nieomylności czynnika nadrzędnego - czyli Partii i Wodza który ideologię interpretuje ${ }^{101}$. W okresie rządów Stalina mit wodza - tak właśnie działającego - uległ spotęgowaniu. Ten pogląd, głoszony najpierw przez polskiego socjologa Aleksandra Hertza - powtarzany później przez innych - zgodny jest $\mathrm{z}$ koncepcją Walickiego.

Definiując ,istotę stalinizmu”, Walicki zawsze utrzymywał, iż jej fenomen ujawnia się w „zniewoleniu umysłów”, w dokonywanej przemocą uniformizacji życia

98 Drukowane w tomie: Totalitaryzmy XX wieku. Idee, instytucje, interpretacje, red. W. Kozub-Ciembroniewicz i in., Kraków 2010, s. 123-132.

99 Mamy na myśli tom: Od projektu komunistycznego do neoliberalnej utopii, Kraków 2013.

100 A. Walicki, Marksizm i skok do królestwa wolności..., s. 385 (książka Tuckera: Stalin in Power. The Revolution from Above 1928-1941 wyszła drukiem w 1990 r.).

101 O tych sprawach pisał w latach 30. socjolog polski Aleksander Hertz: Drużyna wodza, „Przegląd Socjologiczny" 5, 1937, nr 3-4, s. 599-692 (powtórzone w jego wydanym pośmiertnie zbiorze: Szkice o totalitaryzmie, Warszawa 1994), a także: Militaryzacja stronnictwa politycznego, „Przegląd Socjologiczny” 4, 1936, nr 1-2, s. 60-109; Posłannictwo wodza, „Przegląd Socjologiczny” 4, 1936, nr 3-4, s. 341-413. 
duchowego, a czegoś takiego nie było w Rosji dziewiętnastowiecznej, „najlepiej mu znanej"102. Taką też wymowę ma jego książka Marksizm i skok do królestwa wolności. Przekonanie o duchowym zniewoleniu „od wewnątrz” jako podstawie totalitarnej ideologii prowadziło Walickiego do odkrycia Zniewolonego umysłu Miłosza, któremu poświęcił dwie książki ${ }^{103}$.

Nie ma totalitaryzmu bez fenomenu „nowej wiary”. Z tej perspektywy patrząc totalitaryzm komunistyczny jest najbardziej konsekwentny. Doświadczenie zniewolenia człowieka „od wewnątrz” stanowi istotę władzy totalitarnej. „Utopijna idea gospodarki bezrynkowej, świadomie nawiązująca do gospodarki naturalnej i zasadniczo sprzeczna ze złożonością wielkoprzemysłowej gospodarki współczesnej, rzuca wiele światła na losy socjalistycznego eksperymentu w Rosji. Nie jest ona jednak jedynym wytłumaczeniem bolszewickiego totalitaryzmu" - pisał104. Istotą jest fenomen nowej wiary.

Totalitaryzm wytwarza mechanizmy zniewolenia „od wewnątrz". To nie jest tylko dyktatura operująca systemem przymusu i systemem zakazów „w imię utrzymania i umocnienia istniejącej władzy"105. Gdyby tak było, totalitaryzmu nie dałoby się odróżnić od innych represyjnych dyktatur, stosujących przemoc i powodujących znaczne ofiary, zwłaszcza w tych krajach, gdzie opór przeciw dyktaturze okazał się znaczny. Totalitaryzm to przede wszystkim potężne oddziaływanie siły „nowej wiary”, na podobieństwo „nowej religii”. Te tezy autora Zniewolonego umysłu po latach należą z całą pewnością do najważniejszych, które wprowadził do historiografii polskiej.

W książce Marksizm i skok do królestwa wolności Walicki dowartościowuje znaczenie pierestrojki. Przypomnijmy, że polityka Michaiła Gorbaczowa postrzegana była na Zachodzie przez wielu sowietologów jako zręczny manewr taktyczny, mający na celu nic innego jak tylko obronę status quo, i tak też była tłumaczona przez niektórych przedstawicieli silnie antykomunistycznego nurtu w sowietologii zachodniej, jak np. Alaina Besançona, Johna Lenczowskiego, Jeane Jordan Kirkpatrick czy innych ${ }^{106}$.

Andrzej Walicki dopatrywał się w pierestrojce "rozbrojenia moralnego”. Doszedł do przekonania, że „półtotalitarny system radziecki mógłby trwać jeszcze dość długo. Reformy Gorbaczowa odsłoniły ideologiczne bankructwo

102 A. Walicki, Zniewolony umyst po latach..., s. 114.

103 Mam na myśli wspomniane już książki: Spotkania z Miłoszem (1983) i Zniewolony umyst po latach (1993).

104 A. Walicki, Marksizm i skok do królestwa wolności..., s. 20.

105 Przekonująco to wyjaśniał L. Kołakowski, Główne nurty marksizmu..., s. 861.

106 A. Besançon, Czy Gorbaczow może zmienić system?, w: tenże, Świadek wieku. Wybór publicystyki $z$ pierwszego i drugiego obiegu, t. 1, oprac. F. Memches, Warszawa 2006, s. 313-380 (przedruk z „Encounter” 1987, nr 5-6); J. Lenczowski, Od Reagana do Gorbaczowa (wywiad), „Kultura” 1989, nr 1-2, s. 40-49; J.J. Kirkpatrick, Fenomen polityki Ronalda Reagana, Warszawa 1989 (wyd. drugiego obiegu). 
systemu, powodując jego delegitymizację, a następnie upadek"107. Tłumaczył też, iż „gdyby Związek Radziecki wraz z reżimami satelickimi w Europie Środkowo-Wschodniej pozostał totalitarny do samego końca, całkowite załamanie się radzieckiego imperium w latach 1989-1991 byłoby teoretycznie niewytłumaczalne i praktycznie niemożliwe"108.

Wystąpienie Walickiego w postaci książki Marksizm i skok do królestwa wolności pozostaje doniosłym i przekonującym głosem w obronie totalitarnego modelu. W obronie paradygmatu totalitaryzmu jako koncepcji poznawczej i objaśniającej fenomen władzy nowego typu.

„Model totalitarny - pisał Walicki trafnie w książce Marksizm i skok do królestwa wolności - niezbędny jest po to, aby właściwie zrozumieć dwa procesy, dwa szeregi przemian: proces totalitaryzacji i proces detotalitaryzacji. Innymi słowy teoria totalitaryzmu zachowuje swą przydatność, ale wymaga uzupełnienia teorią procesu jego przekształceń, czyli odwrotu od totalitaryzmu"109. Właśnie ów fenomen detotalitaryzacji jest szczególnie ważny, chociaż np. Jerzy Jedlicki napisał, iż termin ten to „niezgrabny neologizm”. W języku polskim niełatwo stworzyć inny i zresztą nie to jest ważne ${ }^{110}$. Walicki - podkreślmy to - nie był twórcą pojęcia „detotalitaryzacji”. Zjawisko wewnętrznych przeobrażeń ustroju totalitarnego odnotowała już Hannah Arendt. Brzeziński stworzył kilkufazowy model odwrotu od totalitaryzmu i proces ten scharakteryzował w swej głośnej książce Wielkie bankructwo (The Grand Failure. The Birth and Death of Communism) - jako trzy odrębne fazy: (1) „komunistyczny autorytaryzm”, (2) „postkomunistyczny autorytaryzm”, (3) „postkomunistyczny pluralizm”111. Nie kwestionując tych propozycji Brzezińskiego, Walicki poszedł tu znacznie dalej - proces rozkładu totalitaryzmu obszernie scharakteryzował i opisał dość szczegółowo, chociaż oczywiście wiele spraw pozostawił otwartymi. „Detotalitaryzacja” to dla Andrzeja Walickiego „stopniowy rozkład, dezintegracja systemu i narodziny w to miejsce czegoś nowego, naznaczonego jednak piętnem tego systemu"112. Proces „detotalitaryzacji” jest organiczny, endogenny. Może on być pełen załamań i nawrotów do totalitarnej spuścizny. Jedno jest pewne - że skuteczny proces retotalitaryzacji pozostaje trudny i chyba nieosiągalny. Nie zna go w każdym razie historia powszechna.

107 A. Walicki, Totalitaryzm i posttotalitaryzm. Próba definicji, w: Społeczeństwa posttotalitarne. Kierunki przemian, red. Z. Sadowski, Warszawa 1991 (materiały z konferencji odbytej w listopadzie 1990 r. w Radziejowicach pod Warszawą), s. 13-26; ten sam tekst w: tenże, Polskie zmagania $z$ wolnościa..., s. 102 (cyt. za tym wyd.).

108 Tamże.

109 Tamże.

110 J. Jedlicki, Supeł Walickiego, „Przegląd Polityczny” 2000, nr 45, s. 19.

111 Oryg. ang.: New York 1989. Wydanie polskie ukazało się nakładem Instytutu Literackiego w Paryżu w 1990 r. (Biblioteka „Kultury”, 456).

112 A. Walicki, Totalitaryzm i posttotalitaryzm..., s. 110. 
Nie jest własną propozycją teoretyczną Walickiego również pojęcie „posttotalitaryzmu", którego używał ${ }^{113}$. Wprowadził je - jak się przyjmuje - Václav Havel w głośnym eseju Siła bezsilnych z 1979 r. ${ }^{114}$ Nie tyle więc w innowacyjnych propozycjach terminologicznych wyraża się wkład Walickiego do debaty nad kryzysem sowieckiego totalitaryzmu, ile $\mathrm{w}$ jego analitycznych rozważaniach, które rekonstruują proces historyczny nie z perspektywy historii wydarzeniowej, ale dziejów idei.

Najważniejszy jest samoistny proces rozkładu totalitaryzmu - i jego definitywny krach, niezależnie od tego, jakimi pojęciami go opiszemy. „Komunizm zaczął się obalać w połowie lat 50 . Za sprawą komunistów, którzy tracili wiarę. Bo to był zły i niewydolny ustrój. Miękł. Kruszył się. Ewoluował. Aż zostały zaklęcia i dekoracje" - powiedział Walicki w drukowanym już pośmiertnie wywiadzie udzielonym Jackowi Żakowskiemu w „Polityce” 115 . Komunizm nie został obalony. On „załamał się utraciwszy wiarę w siebie"116. Za George’em F. Kennanem powtórzył Walicki, że pokojowy upadek ZSRR to ,jedno z najdziwniejszych i najbardziej wstrząsających wydarzeń, jakie można było sobie wyobrazić"117.

Nie Rosja wygenerowała totalitaryzm, ale to ona padła jego pierwszą ofiarą ${ }^{118}$. Ta myśl Walickiego pozostaje zasadnicza. Bez niej nie sposób zrozumieć jego stanowiska w sporze o genezę i istotę totalitaryzmu. Znaczenie totalitarnego komunizmu pozostaje ogólnoludzkie. Rosja była areną tego dziejowego eksperymentu. W myśl profetycznej wizji Piotra Czaadajewa dała wielką lekcję pokazową światu. Oczywiście okazała się ona negatywną. I winna być przestrogą dla ludzkości.

Zagadnienie totalitaryzmu ma oczywisty związek ze sporami o charakter ustrojowy PRL, o charakter i bilans tego okresu w dziejach Polski, a nikogo przekonywać nie trzeba, iż sprawy te mają swój realny wpływ na teraźniejszość - na świadomość historyczną Polaków doby dzisiejszej. Z tych powodów do sporu o dziedzictwo PRL Walicki wracał na przestrzeni ostatnich kilkunastu lat niewątpliwie często ${ }^{119}$. Podejmując te sprawy, podkreślał zazwyczaj silną ideologizację i polityzację

113 Tamże.

114 V. Havel, Siła bezsilnych $i$ inne eseje, wybór A.S. Jagodziński, Warszawa 2011.

115 „Polityka” 16-22 IX 2020.

116 A. Walicki, Marksizm i nieudany „skok do królestwa wolności”, w: tenże, Polska, Rosja, marksizm... (2011), s. 445.

117 Cyt. za: S. Kotkin, Armageddon Averted. The Soviet Collapse 1970-2000, Oxford 2001 (art. Walickiego, Marksizm i nieudany „skok do królestwa wolności”..., s. 444).

118 W tej kwestii poglądy Walickiego nader wyraźnie zbiegają się z przesłaniem Mariana Zdziechowskiego, najbardziej antysowieckiego intelektualisty polskiego doby międzywojennej.

119 A. Walicki, Demony PRL-u, „Res Publica Nowa” 1993, nr 3/54, s. 6-13 (ten sam tekst pt. Dziedzictwo PRL wszedł do tomu Polskie zmagania z wolnością..., s. 113-123). Na temat problemu „totalitaryzm a PRL” Walicki ogłosił także kilka innych artykułów: Zrozumieć przeszłość, „Zdanie” 1990, nr 2-3, s. 2-8; Totalitaryzm, czyli o potrzebie rozrachunków uczciwych, „Polityka Polska” 1990, nr 1(15), s. 10-16; Czy PRL była państwem totalitarnym?, „Polityka” 21 VII 1990. 
dyskusji o totalitaryzmie w Polsce obecnej, jej przemożne uzależnienie od wielu czynników, politycznych, ideologicznych, psychologicznych ${ }^{120}$. Autor Polskich zmagań $z$ wolnościq uważał, iż niewątpliwie opozycja w Polsce, przyjmując schemat czarno-biały w krytyce systemu PRL, potrzebowała pojęcia totalitaryzmu.

Dla piszącego niniejsze słowa jedno nie ulega wątpliwości. Teoria totalitaryzmu wymaga reinterpretacji poprzez wprowadzenie i zastosowanie pojęcia „detotalitaryzacji”, inaczej pozostanie koncepcją martwą. Walicki ją zmodyfikował i nadał jej nowy sens. Jak już to zaznaczono, Walicki nie odrzucał modelu totalitarnego a limine, jako nieprzydatnego do powojennej historii Polski. Miał świadomość, że odrzucenie pojęcia totalitaryzmu spowoduje, że wiele utraci na ostrości cezura przełomu 1956 r., której ogromne znaczenie nie ulega wątpliwości dla każdego, kto historię Polski po II wojnie światowej rozpatruje rzetelnie i bez uprzedzeń. Akcentował mocno, iż w Polsce był to „totalitaryzm niedokończony”, jego budowę przerwała bowiem przedwcześnie śmierć Stalina i proces odwilży, którego pierwsze oznaki pojawiły się już w końcu 1954 r. Mocno też podkreślał cezurę „polskiego Października” jako punktu zwrotnego w powojennej historii narodu. „Polska przestała być państwem totalitarnym w październiku 1956 roku. Nadal rządziła nią zdemoralizowana partia totalitarna, w rosnącym stopniu złożona z elementów skorumpowanych i oportunistycznych" - powiedział Zbigniew Brzeziński, polityk i teoretyk totalitaryzmu, którego nie sposób posądzić o skłonności do rehabilitacji systemu PRL ${ }^{121}$. Walicki lubił te słowa cytować.

W polskich realiach rok 1956 był cezurą zwrotną i rzeczywistym przełomem. XX Zjazd KPZR był potężnym ciosem w mit nieomylności najwyższego czynnika, zadecydował o dyskredytacji „,nowej wiary”, bez której nie ma „zniewolenia umysłów" i nie ma totalitaryzmu. W dziejach komunistycznej utopii cezura, jaką wyznacza ten rok, zajmuje szczególne miejsce. W Związku Sowieckim proces rozkładu „ideokracji” totalitarnej był przecież bardziej złożony i długotrwały. Październik 1956 r. nie przyniósł Polakom wolności politycznej, ale był wielkim osłabieniem siły i legitymizacji ideologii komunistycznej, jej dynamiki przede wszystkim. Doniosłość tego przełomu nie została zrazu przez Polaków dostrzeżona. Z tej perspektywy patrząc, przyniósł jednak wewnętrzne wyzwolenie - przede wszystkim dla inteligencji polskiej. „Ludzie, którzy byli, tak jak ja, ofiarami stalinizmu, nie mogli nie rozpoznać zmiany, ponieważ natychmiast odczuli ją we własnym życiu" ${ }^{122}$. Nieodwołalnie uruchomiony został proces dezideologizacji życia i dezideologizacji samej partii, która przekształcała się stopniowo w aideologiczny aparat władzy. Nie uległy zmianie instytucjonalne formy ustrojowe PRL, nie zmieniła się forma rządów ani zasadniczo nie zmienił się ustrój gospodarczy.

120 A. Walicki, Totalitaryzm i posttotalitaryzm..., s. 97.

121 Wywiad Brzezińskiego udzielony piszącemu niniejsze słowa jesienią 2005 r.; zob. Z. Brzeziński, M. Kornat, Pięćdziesiąt lat później, „Przegląd Polityczny” 2006, nr 79/80, s. 141.

122 A. Walicki, Polskie zmagania z wolnością..., s. 454, przyp. 7. 
Nadal trwały jeszcze elementy totalitarnego porządku, na co zwracali uwage historycy Paweł Machcewicz czy Andrzej Friszke ${ }^{123}$. Ideologia utraciła wszakże ofensywność i siłę zniewalania, mimo wysiłków propagandy.

Nastąpiła przede wszystkim emancypacja nauki i humanistyki, jej rozwój, który nie może być porównywalny z sytuacją w żadnym $\mathrm{z}$ krajów bloku wschodniego. Przełom październikowy zaowocował świetnym rozwojem historiografii, sukcesami socjologii, warszawską szkołą historyków idei. Szczególne uwarunkowania historyczne powojennej Polski, która z procesu „detotalitaryzacji” skorzystała najwięcej wśród narodów Europy Środkowo-Wschodniej, domagają się zrozumienia.

W sprawie cezury 1956 r. Walicki odwołuje się szeroko do rozważań Hanny Świdy-Ziemby, której analiza postaw inteligencji polskiej wobec władzy totalitarnej w okresie stalinowskim była nowatorska ${ }^{124}$. W świetle jej badań przełomowy charakter cezury $1956 \mathrm{r}$. w realiach polskich uzyskuje nowe, dodatkowe uzasadnienie. Jest oczywiste, iż Zniewolony umyst pisany po $1956 \mathrm{r}$. byłby po prostu niezrozumiały. Zapewne nie mógłby zostać napisany.

Nie sposób nie powiedzieć, że spór o charakter PRL czy też w ogóle o granice stosowalności pojęcia totalitaryzm będzie trwał zapewne jeszcze długo. Ani Brzeziński, ani Walicki go nie zakończyli. Jedno natomiast wydaje się bezsporne. Zrozumieć, czym był totalitaryzm to rozpoznać istotę mechanizmów psychicznego zniewolenia, zniewolenia „od wewnątrz", zniewolenia może bardziej dotkliwego niż zewnętrzny przymus. „Szczególnie groźne [jest] przyjęcie ideologii sankcjonującej gwałt dokonywany na organizmie społecznym, narzucenie siłą porządku społecznego tłumowi, mierzwie ludzkiej" - pisała Hanna Świda-Ziemba ${ }^{125}$. Racjonalizowanie to na swój sposób też lawirowanie, tak, aby „realizacja własnych wartości była choć częściowo możliwa - było sprawą trudną i złożoną. Jednakże traktowaliśmy to jako naturalny nakaz moralny" 126 .

Po 1956 r. zaczął wytwarzać się swoisty konsensus między władzą a społeczeństwem ${ }^{127}$. Konsensus taki z pewnością działał w realiach „Polski popaździernikowej”. Do tej Polski teoria totalitaryzmu już nie ma zastosowania. Model totalitarny - pisał trafnie Dariusz Jarosz - okazał się dużo bardziej owocny naukowo do wyjaśniania

${ }^{123}$ P. Machcewicz, Zmiana czy kontynuacja? Polska przed i po Październiku '56, w: PRL - trwanie i zmiana, red. D. Stola, M. Zaremba, Warszawa 2003, s. 119-158; A. Friszke, Jakim państwem była Polska po 1956 r.? Spór historyków, „Więź” 1996, nr 2, s. 131-146.

${ }^{124}$ H. Świda-Ziemba, Stalinizm i społeczeństwo polskie, Warszawa 1991 (wcześniej zarys tej książki ogłoszony był w szkicu: Stalinizm i społeczeństwo polskie, w: Stalinizm, red. J. Kurczewski, Warszawa 1989).

125 Tamże, s. 81.

126 Tamże, s. 47.

127 Socjolog Piotr Sztompka definiuje dwa rodzaje konsensusu: „konsensus pozytywny” i „konsensus negatywny"; zob. tenże, Socjologia. Analiza społeczeństwa, Kraków 2002, s. 544. Na czynnik konsensusu i przystosowania we wszystkich ustrojach autorytarnych zwracał uwagę Franciszek Ryszka. 
ambicji i dążeń władzy, a „mniej do analizy relacji władza-społeczeństwo i zachowań tego drugiego" ${ }^{128}$. Proces „detotalitaryzacji” ujawnia społeczne mechanizmy wytwarzania się konsensusu i przystosowania. Zagadnienie to pozostaje z pewnością doniosłym problemem historiograficznym. Jak dalece sięgało poparcie społeczne dla tej formy ustrojowej PRL, jaka wyłoniła się z październikowej rewolucji pokazać powinny przyszłe rzetelne badania historyczne. Walicki uważa, że było ono znaczące, że obejmowało większość społeczeństwa. Zapewne różnie rozkładało się to w poszczególnych okresach.

Zatrzymując się przy wypowiedziach najbardziej rzetelnych historyków, przypomnijmy, że Paweł Machcewicz, rozpatrując problem ciągłości i zmiany w ustroju PRL po 1956 r., doszedł do wniosku, iż na pytanie, czy Polska po Październiku była państwem totalitarnym, „nie ma w pełni naukowej odpowiedzi”. Mając świadomość doniosłości zmian, jakie przyniósł Październik, podkreślał zarazem przetrwanie „cech konstytutywnych” systemu, a wśród nich „monopol polityczny i ideologiczny” oraz kontrolę państwa-partii nad gospodarką i „znaczącą częścią życia społecznego" 129 . Zasadniczo podzielam ten pogląd, co jednak w żadnej mierze nie sprawia, abym wątpił w słuszność tezy Walickiego o procesie detotalitaryzacji, zachodzącym w ZSRR, państwach bloku wschodniego, a zwłaszcza w Polsce.

Warto $\mathrm{w}$ tym miejscu przypomnieć jeszcze uwagi Jerzego Jedlickiego, który zastanawiał się, „czy dzieje po Październiku godzi się opisywać jako "proces wewnętrznej detotalitaryzacji« rzecz to sporna, bowiem to niezgrabne słowo, nawet opatrzone zastrzeżeniem "zygzakowata« sugeruje mimo wszystko jakiś ciągły i ukierunkowany ruch w stronę oświeconej liberalności. Ruchu takiego nie było jednak w wyboistych dziejach Polski Ludowej: poziom swobód obywatelskich końca roku 1956 został ponownie osiągnięty, a i to na krótko, dopiero we wrześniu 1980 roku i ponownie dopiero w przeddzień końca systemu"130. Niewątpliwie Jerzy Jedlicki miał rację, kiedy pisał, że zakres praw obywatelskich, jaki społeczeństwo polskie osiągnęło $\mathrm{w}$ realiach systemu PRL po Październiku, został w dużej mierze utracony i odzyskany dopiero po „wybuchu »Solidarności «". Ale to nader trafne stwierdzenie dotyczy sfery instytucjonalnej, nie duchowej. Co zaś ważniejsze, Październik zburzył mit nieomylności partii, przyniósł zmierzch stalinowskiej „ideokracji” i spowodował upadek systemu masowej mobilizacji. Dał więc inteligencji polskiej wewnętrzne wyzwolenie, to zatem, co najważniejsze. Ustalenia Walickiego mają więc nieodparte uzasadnienie. To właśnie akcentował Walicki.

Polska stanu wojennego pozostaje dla Walickiego państwem o rządach odpowiadających modelowi autorytarnemu, a nie totalitarnemu. W głośnym szkicu

128 D. Jarosz, Polacy a stalinizm 1948-1956, Warszawa 2000, s. 229.

129 P. Machcewicz, dz. cyt., s. 157-158.

130 J. Jedlicki, dz. cyt., s. 19. 
Paradoksy Polski Jaruzelskiego Walicki tłumaczył, że „realny socjalizm nie musi być totalitarny” ${ }^{131}$. „Realny socjalizm” w polskim wydaniu był po 1956 r. rezultatem „detotalitaryzacji”, był „produktem” niewątpliwego odwrotu od totalitaryzmu. W imię rzetelności poznawczej i ścisłości pojęć uczył, że traktowanie stanu wojennego jako odrodzenia totalitaryzmu, jako neostalinowskiej rewolty - jest nadużyciem, gdyż niczego nie tłumaczy, a co najwyżej daje uczestnikom działań opozycji demokratycznej poczucie, że prowadzą zmagania $\mathrm{z}$ totalitaryzmem.

Walicki podkreślał, że totalitarny komunizm nie jest relatywizmem moralnym, pokrewnym postmodernizmowi ${ }^{132}$. A tak właśnie dowodziła Anna Pawełczyńska, której słowa wydają się jednak trafne, ale raczej w odniesieniu do realiów powstałych po załamaniu się "nowej wiary” ${ }^{33}$. Wyzwolenie z totalitaryzmu - przekonywał autor Polskich zmagań $z$ wolnościq - dokonało się nie poprzez absolutyzm moralny, ale poprzez pewien relatywizm, poprzez historyzm ${ }^{134}$. Relatywizm ten, będący swego rodzaju sceptycyzmem, obnażał nonsens wiary $\mathrm{w}$ „prawa historii” i przez to prowadził do uodpornienia na potężne oddziaływanie ideologii komunistycznej. Walicki to doświadczenie zrozumiał i książka Zniewolony umyst po latach oraz szkic Leszek Kołakowski i warszawska szkoła historii idei są tego wymownym potwierdzeniem ${ }^{135}$.

Zasadniczą tezą, której bronił Andrzej Walicki, jest pogląd, że „realnego socjalizmu" nie można utożsamiać z komunistycznym totalitaryzmem ${ }^{136}$. Że ideokratyczna władza totalitarna jest fenomenem jakościowo innym od autorytaryzmu doby Gomułki, Gierka czy Jaruzelskiego. Że „realny socjalizm” nie musi być totalitaryzmem. Historię Polski Ludowej Walicki rozpatruje bez tych emocji, które z reguły dochodzą do głosu u podejmujących te problemy uczestników dawnej opozycji demokratycznej. Nie jest to łatwe, bo przecież walkę o Polskę demokratyczną wszyscy bardzo świeżo mamy w pamięci. Nie jest łatwo przyjąć, że wówczas $\mathrm{w}$ walce rządu i opozycji racje mogły być podzielone. Ale warunkiem wiarygodności historyka jest uznanie tego stanu rzeczy. Autor Polskich zmagań $z$ wolnością nas o tym przekonuje.

${ }^{131}$ Pogląd taki Walicki wyraził już w 1985 r., wygłaszając referat na VIII Rocznej Konferencji Izraelskiego Towarzystwa Studiów Słowiańskich i Wschodnio-Europejskich na Uniwersytecie Ben Guriona w Beer Szewie. Tekst ukazał się po angielsku jako Paradoxes of Jaruzelski's Poland, „Archives Européennes de Sociologie" 26, 1985, nr 2, s. 167-191; wersja polska weszła do tomu Polskie zmagania $z$ wolnościa... (stamtąd cytat, s. 32).

132 A. Walicki, Kartki z dziennika..., s. 392.

133 A. Pawełczyńska, Głowy hydry. O przewrotności współczesnego zła, Lublin 2004.

134 Niezmiernie ważny jest $\mathrm{w}$ tej perspektywie tekst B. Baczki, Kryptoproblemy $i$ historyzm, w: tenże, Człowiek i światopoglądy, Warszawa 1965, s. 373-418.

135 A. Walicki, Leszek Kołakowski i warszawska szkoła historii idei, „Aletheia” 1987, nr 1, s. 121-153 (ogłoszone najpierw w j. ang. On Writing of the History of Ideas. Leszek Kołakowski and the Warsaw School of the History of Ideas, „Critical Philosophy” (Sydney) 1, 1984, nr 2, s. 5-23).

136 A. Walicki, Totalitaryzm i posttotalitaryzm..., s. 97. 
Punkt widzenia Andrzeja Walickiego nie jest zapewne ostatnim słowem w sporze o charakter ustrojowy PRL. Jego interpretacja procesu „detotalitaryzacji” wywołała różne komentarze - także krytyczne i polemiczne ${ }^{137}$. Do spraw tych nauka polska będzie z pewnością niejednokrotnie jeszcze powracać. Być może nigdy nie powstanie tu consensus omnium, bo też uwarunkowania ideowo-polityczne nieprędko przestaną oddziaływać na myślenie społeczeństwa polskiego o najnowszej historii.

Z Walickim można się nie zgadzać, można brać za punkt wyjścia inne obserwacje i doświadczenia biograficzne, ale niepodważalne jest to, że stawia on ważne problemy, w ich rozwiązywaniu nie uznaje konformizmu ani nie ulega kolektywnym nastrojom. Potrafi iść pod prąd, zwalcza „czarną legendę” PRL, lecz nie rezygnuje $\mathrm{z}$ krytycznego stosunku do przeszłości, jakby zachowując $\mathrm{w}$ pamięci dewizę konserwatystów krakowskich, że prawdziwa historia (historia krytyczna) jest mistrzynią skutecznej i umiejętnej polityki, i na odwrót: „fałszywa historia jest mistrzynią fałszywej [błędnej] polityki” - jak to ujął dobitnie Józef Szujski na początku lat 70. XIX w. ${ }^{138}$ Nie ma wątpliwości, że bez rzetelnej oceny dziejów Polski Ludowej, oceny wolnej od mitów i jednostronności, nie będzie rzetelnej oceny Polski dzisiejszej, jej blasków i cieni.

O ile w kręgach akademickich pojęcie „totalitaryzmu” zawsze wzbudzało mniej lub bardziej daleko idące zastrzeżenia i krytykę, to w świadomości potocznej, we współczesnych dyskusjach wokół powojennej historii Polski, pojęcie to było $\mathrm{i}$ jest $\mathrm{w}$ sposób wieloraki nadużywane lub opacznie rozumiane. W niemieckiej historiografii współczesnej bywa usuwane jako termin par excellence polityczny. Podejście takie utrwaliło się i ma coraz więcej zwolenników ${ }^{139}$.

Andrzej Walicki występuje stanowczo przeciwko naużywaniu terminu „totalitaryzm". O totalitaryzmie PRL do końca jej istnienia mówiła opozycja demokratyczna. W obecnej Polsce nadużywanie to ma miejsce nie tylko w kręgach radykalnej prawicy, dla której ustrój PRL miał charakter totalitarny do samego końca. Nie brakuje i dzisiaj studiów i rozpraw dowodzących, że system PRL nie wyzbył się do końca swej totalitarnej „istoty” 140 . Zwracając się przeciwko tym uproszczeniom, bronimy prawdy historycznej, bronimy rzetelności wiedzy historycznej, ścisłości

137 Z. Krasnodębski, Polityka i moralność - w ogóle, u nas i gdzie indziej, „Znak” 1997, nr 7, s. $4-19$.

${ }^{138}$ J. Szujski, O fałszywej historii jako mistrzyni fałszywej polityki: rozprawy i artykuły, red. H. Michalak, Warszawa 1991.

139 Nastawienie takie przyniosło próby porzucenia koncepcji totalitaryzmu i operowania koncepcją dyktatury jako fenomenem, który odnosi się zarówno do Hiszpanii Franco, Niemiec Hitlera, Polski Piłsudskiego, jak i ZSRR Stalina. Zabieg tego rodzaju nie znosi granicy między ustrojami totalitarnymi a autorytarnymi. Wymowny przykład takiego zabiegu przyniosła praca Gerharda Besiera, mająca w zamyśle autora dać nowe ujęcie dziejów Europy XX stulecia: Das Europa der Diktaturen. Eine neue Geschichte des 20. Jahrhunderts, Münich 2006.

${ }^{140}$ Tak uważała np. A. Pawełczyńska, dz. cyt. 
ocen i precyzji pojęć, które muszą odpowiadać rzeczywistości historycznej, a potrzeba zrozumienia przeszłości to ważny postulat.

Studia Walickiego nasuwają sporo refleksji nad stosunkiem do historii najnowszej w społeczeństwie Polski dzisiejszej. Profesor z pasją dowodził, w jak poważnym stopniu jednostronny antykomunizm zaciemnia złożoność tej doby naszej najnowszej historii i przesłania odrębność i specyfikę położenia Polski w obozie państw „realnego socjalizmu” na przestrzeni dziesięcioleci powojennych. Powstaje w ten sposób przeszkoda, która uniemożliwia obiektywizację ocen i poglądów na okres Polski Ludowej.

W przedmowie do polskiego wydania swej książki Marksizm i skok do królestwa wolności Walicki ubolewał nad „zawstydzającą płytkością polskiego antykomunizmu" doby współczesnej ${ }^{141}$. Słusznie też zauważył, że czym innym jest antykomunizm okresu zimnej wojny, czym innym zaś antykomunizm z czasów schyłku „realnego socjalizmu”, a jeszcze czymś innym jest antykomunizm dzisiaj w krajach postkomunistycznych. Podejmował więc problem antykomunizmu, broniąc historycznego kompromisu, jaki dokonał się przy Okrągłym Stole ${ }^{142}$. Dystansując się od antykomunizmu, tworzył dogłębne uzasadnienie postawy antytotalitarnej.

Pytanie o to, czy PRL była państwem totalitarnym - będzie niewątpliwie jeszcze powracać. Z pewnością dyskusja wokół tych zagadnień pozostaje w Polsce uwikłana w spory ideowe. Nadmieńmy tylko, że z dystansem do przemyśleń i propozycji Walickiego odnosili się także ludzie bynajmniej nie przeciwni jego ogólnemu spojrzeniu na dzieje Polski w XX w., jak Jerzy Jedlicki czy Adam Michnik, który ostatnio powrócił krótko do tej kwestii w jednym ze swoich wywiadów, podtrzymując swoje pełne dystansu podejście do koncepcji Walickiego, a zwłaszcza do tezy o transformacji reżimu PRL w państwo autorytarne ${ }^{143}$.

Nie da się zaprzeczyć, że autor Polskich zmagań $z$ wolnościa dał swoimi refleksjami impuls do jednej z najbardziej inspirujących dyskusji wokół ustroju powojennej Polski w naszej historiografii.

$* * *$

Kluczowe koncepcje Andrzeja Walickiego jako historyka idei można streścić $\mathrm{w}$ następujących założeniach, którym był konsekwentnie wierny przez ponad sześćdziesiąt lat pracy akademickiej i pisarskiej.

Przede wszystkim jest to klasyczna zasada historyzmu, a więc rekonstrukcji genezy i konsekwencji danej koncepcji intelektualnej. Ale nie ma uniwersalnego modelu ujmującego narodziny i zmierzch rozmaitych idei. Nie ma i „nadhistoryczności”. Jak ujął to Fryderyk Engels, „każdy odrębny ciąg ewolucji historycznej

141 A. Walicki, Marksizm i skok do królestwa wolności..., s. 12.

142 Tenże, Sprawiedliwość okresu przejściowego i walki polityczne, w: tenże, Polskie zmagania $z$ wolnościq..., s. 133-174.

143 A. Michnik, Kto się boi, powinien spać pod pierzyną, „Zdanie” 2021, nr 1, s. 3-16. 
badać należy oddzielnie i porównywać z innymi; nic nie pomoże tutaj posługiwanie się »uniwersalnym kluczem jakiejś ogólnej historyczno-filozoficznej teorii, której największą zaletą jest jej nadhistoryczność «"144. W ogóle trudno nie podkreślić, że poprzez historyzm następowało wyzwolenie spod panowania ideologicznych schematów wulgarnego marksizmu doby stalinowskiej. Dzieje warszawskiej szkoły historii idei poświadczają to zjawisko.

Nie od dzisiaj wiadomo, że historyk idei może zajmować wobec przeszłości, którą bada, postawę albo służebną, albo władczą. Ta pierwsza polega na rozpatrywaniu określonych idei ściśle w kontekście swojego czasu. Na wydobyciu z tekstu tego, co on zawiera. Druga polega na określonej interpretacji, na którą wpływ ma oczywiście czas, w którym historyk żyje i działa. Walicki był niewątpliwie przedstawicielem tego „władczego” podejścia do historii idei.

W szczególności znamienna dla Walickiego jest komparatystyczna orientacja. Otwiera ona niezwykłe w swym rodzaju pole dociekań nad „krążeniem” idei, paralelnością rozmaitych kierunków myśli w różnych krajach, wreszcie ich wzajemnym oddziaływaniem i inspirowaniem. Takiej historiografii idei nie uprawiał nikt w Polsce przed Walickim - za wyjątkiem Mariana Zdziechowskiego z wczesnej jego twórczości, znaczonej takimi dziełami jak Mesjaniści i słowianofile czy Byron i jego wiek.

Istotne znaczenie w podejściu Walickiego do idei politycznych, społecznych, filozoficznych czy religijnych ma zasada empatii, a więc umiejętność zrozumienia stanu psychicznego i duchowego ludzi, którzy je stworzyli czy też nimi się posługiwali dla wyrażenia swoich myśli. Nie odstępował od niej w zasadzie we wszystkich swoich pracach - niezależnie od tego, czy chodziło o idee socjalizmu, mesjanizmu, liberalizmu bądź narodnictwa.

W rozumieniu Walickiego historyk idei powinien być raczej tłumaczem przeszłości niż sędzią. Celem jego dociekań pozostaje przede wszystkim objaśnianie, a nie sądzenie. W tym z pewnością tkwi fenomen Walickiego jako intelektualisty. To nastawienie też zdaje się tłumaczyć jego pełne rezerwy podejście do uproszczonych ocen moralnych. Bardzo ostro wypowiedział się pod koniec życia za skłonnością do moralizowania, którego hipertrofię widział w polskim życiu publicznym.

W badaniu idei wydobywanych z przeszłości ważniejsza jest geneza danej koncepcji, a mniej liczy się dociekanie „istoty” zjawiska, które ta idea wyraża. Orientacja Walickiego jest nastawiona na studium danej koncepcji raczej jako pewnego fenomenu, a nie dotarcie do istoty zjawiska, które ona reprezentuje. A zatem mamy u niego zwrócenie się przeciw esencjalizmowi - na rzecz fenomenalizmu.

Wreszcie podkreślić trzeba, iż Andrzej Walicki zawsze wyznawał przekonanie, że „idee mają konsekwencje" ${ }^{145}$. Nie są dekoracją, ale kształtują realia życia.

144 A. Walicki, Polska, Rosja, marksizm. Studia z dziejów marksizmu i jego recepcji, Warszawa 1983, s. 131-132.

145 Sformułowanie tytułowe $\mathrm{z}$ książki Ideas Have Consequences pióra Richarda M. Weavera (1948). 
Wszelkie „wielkie ruchy historyczne potrzebują ideologicznej legitymizacji”. Jako historyk podkreślał, że nie należy nie doceniać roli idei w historii ${ }^{146}$. Historia idei jak zwykł był uważać - „odsłania utajone podstawy ludzkich działań” i pozwala zrozumieć „wpływ wielkich idei na długofalowe procesy dziejowe”.

Nie będzie nie na miejscu zauważyć, że Andrzejowi Walickiemu przyświecała idea określonej misji intelektualnej. Swoją pracę akademicką i pisarską postrzegał jako program życia, a nie gabinetowe zajęcie. Misja, powołanie, cel - łączą się tu w jedno. Tak pojęta misja wykracza poza to, co jest tylko celem poznawczym, i staje się zadaniem ,intelektualno-moralnym”.

Cenił sobie zawsze jednoznaczność. Język, którego używał, był klarowny i pozbawiony ozdobników. Chodziło mu zawsze o to, aby możliwie precyzyjnie wyrazić to, co najtrudniejsze - ale najprościej. Takie pisarstwo ma swoje znaczenie, albowiem w naszych czasach - nawet w życiu akademickim - bywa o nie trudno.

Był przeciwnikiem tego, co Miłosz nazwał „myśleniem stadnym”, i zwracał się przeciw takim tendencjom często bardzo ostro. Potrafił iść pod prąd. Nie ulegał zbiorowym emocjom, pozostając indywidualistą. Ale - co bardzo istotne - tę wartość, jaką jest naród, stawiał wysoko. Identyfikację z tą wspólnotą ludzką pojmował jako coś niezbywalnego.

Nie będzie ani nadużyciem, ani uproszczeniem stwierdzenie, że humanistyka polska $\mathrm{w}$ XX w. wydała niejedną ważną myśl, ale sporo z tych osiągnięć nie zostało wprowadzonych do międzynarodowego obiegu poprzez tłumaczenia na języki obce. Powiedzieć to trzeba choćby o polskich sowietologach doby międzywojennej. Nie dotyczy to jednak Andrzeja Walickiego. Otóż właśnie z tego jeszcze powodu jego pozycja pozostaje $\mathrm{w}$ polskim życiu umysłowym zupełnie wyjątkowa. Jest tak dlatego, że solidna porcja $\mathrm{z}$ tego, co miał do powiedzenia, zaistniało w obiegu światowym. Monografia $W$ kręgu konserwatywnej utopii. Struktura i przemiany rosyjskiego słowianofilstwa miała przekład angielski i dwa wydania (1975 i 1989) ${ }^{147}$, a także tłumaczenia na język włoski (1973) i ukraiński (1998). Dwa tomy studiów z filozofii i myśli polskiej doby romantyzmu ukazały się jako Philosophy and Romantic Nationalism. The Case of Poland (1982 i 1994) oraz The Enlightenment and the Birth of Modern Nationhood. Polish Political Thought from Noble Republicanism to Tadeusz Kościuszko (1989). Książki Legal Philosophies of Russian Liberalism $(1987,1992)$ oraz Marxism and the Leap to the Kingdom of Freedom. The Rise and Fall of the Communist Utopia (1995) w ogóle powstały po angielsku. Last but not least wreszcie tom artykułów oraz esejów Rosja, katolicyzm i sprawa polska ukazał się i po rosyjsku (2012).

$\mathrm{Z}$ upodobaniem i krytycznie wypowiadał się o Polsce uwikłanej w wewnętrzne konflikty, niewolnej od tych wszystkich chorób, które dawały znać o sobie

146 A. Walicki, Zarys myśli rosyjskiej..., s. 96.

147 Tenże, The Controversy over Capitalism. Studies in the Social Philosophy of Russian Populists, Oxford 1969. 
w przedrozbiorowej jej historii i dobie międzywojennej. „Z wielkiej liberalnej myśli wzięliśmy tylko Hayeka, który uważał, że sprawiedliwość społeczna jest szkodliwym mitem” - powiedział nie na długo przed śmiercią ${ }^{148}$. „Polska ma większe szanse jako zachód Wschodu niż jako peryferie Zachodu” - powtarzał podobnie jak Jerzy Giedroyc ${ }^{149}$. Ale jednak „mocno należymy do Wschodu, chociaż bardzo chcemy widzieć siebie jako część Zachodu"150. To tylko niektóre z tych uwag, których na tym miejscu nie będziemy analizować, poprzestając na przywołaniu trzech powyższych - pars pro toto.

Publicystykę Walickiego poświęconą sporom już o Polskę powstałą w wyniku ugody Okrągłego Stołu zebrano ostatnio w trzech obszernych tomach. Całość nosi znamienny tytuł: $P R L i$ skok do neoliberalizmu. Wolno powiedzieć, że wyraża się w nim bardzo trafnie to, co stanowi przewodnią myśl zmarłego Profesora ${ }^{151}$. Pojęcia neoliberalizmu jako tożsamego $\mathrm{z}$ leseferyzmem ekonomicznym używał on $\mathrm{z}$ całą świadomością, przede wszystkim po to, aby pokazać, że to tylko jedna z koncepcji biorących początek z bogatej tradycji myśli liberalnej.

Kim był w swoich czasach i długim życiu? Oczywiście profesorem akademickim i pisarzem. Ale to nie wszystko. Jako historyk idei pozostał „widzem i uczestnikiem XX stulecia” - jak to ujął Bronisław Łagowski, przywołując znane sformułowanie z książki Raymonda Arona - Widz i uczestnik ${ }^{152}$. I jeszcze jedno trzeba podkreślić. Jak sam powiedział Walicki o sobie - jego życie to „tylko ilustracja kondycji inteligenta zanurzonej $\mathrm{w}$ realia PRL"153. Zapewne sformułowanie to można by rozciągnąć, mówiąc również o „zanurzeniu” w historię XX stulecia jako czasy dwóch wojen światowych i panowania totalitaryzmów.

\section{Bibliografia}

\section{Źródła}

J. Giedroyc, C. Miłosz, Listy 1973-2000, oprac. M. Kornat, Warszawa 2012

L. Kołakowski, A. Walicki, Listy 1957-2007, podał do druku A. Walicki, oprac. H. Citko, Warszawa 2018, s. 191-193

List Wiktora Sukiennickiego do Czesława Miłosza, 12 I 1968 r., Instytut Polski i Muzeum Sikorskiego, Londyn, Kolekcja W. Sukiennickiego, sygn. 214

A. Walicki, Spotkania z Miłoszem, Londyn 1983 [listy autora do Czesława Miłosza]

148 J. Żakowski, Ostatni wywiad z prof. Walickim: Jesteśmy pół na pół, „Polityka” 16-22 IX 2020.

149 A. Walicki, Czy jestem „dysydentem”?, „Zdanie” 2005, nr 1-2, s. 44.

${ }^{150}$ J. Żakowski, dz. cyt.

151 PRL i skok do neoliberalizmu, t. 1: Jaruzelski, Solidarność, zdrada elit, t. 2: Antykomunizm zamiast wolności. Porachunki inteligenckie, t. 3: Fałszowanie historii, nacjonalizm, niegodziwości III RP, red. J. Schiller-Walicka, P. Dybicz, Warszawa 2021.

152 R. Aron, Widz i uczestnik, rozmawiają J.-L. Missika, D. Wolton, tłum. A. Zagajewski, Warszawa 1993.

153 A. Walicki, Zniewolony umyst po latach..., s. 11. 


\section{Prace Andrzeja Walickiego (cytowane w artykule)}

The Controversy over Capitalism. Studies in the Social Philosophy of Russian Populists, Oxford 1969

Czy jestem „dysydentem”?, „Zdanie” 2005, nr 1-2, s. 43-48

Czy PRL była państwem totalitarnym?, „Polityka” 21 VII 1990

Demony PRL-u, „Res Publica Nowa” 1993, nr 3/54, s. 6-13 (ten sam tekst pt. Dziedzictwo PRL wszedł do tomu Polskie zmagania $z$ wolnością. Widziane z boku, Kraków 2000, s. 113-123)

Idea narodu w polskiej myśli oświeceniowej, Warszawa 2000 (wyd. ang.: The Enlightenment and the Birth of Modern Nationhood. Polish Political Thought from Noble Republicanism to Tadeusz Kościuszko, tłum. E. Harris, Notre Dame (Ind.) 1989)

Idea wolności u myślicieli rosyjskich. Studia z lat 1955-1959, Kraków 2000 (Jagiellońskie Studia z Filozofii Rosyjskiej, 3)

Idee i ludzie. Próba autobiografii, Warszawa 2010

Idee słowiańskie i filozoficzny romantyzm przed Powstaniem Listopadowym, w: S. Borzym, H. Floryńska, B. Skarga, A. Walicki, Zarys dziejów filozofii polskiej 1815-1918, Warszawa 1983, s. 9-133

Kartki z dziennika 2011-2016, „Zdanie” 2016, nr 1/2, s. 15-24

Katolicyzm nie był jedyna polska tradycją, wywiad udzielony S. Sierakowskiemu dla dodatku „Europa” do pisma „Dziennik.pl” z 5 XI 2007

Leszek Kołakowski i warszawska szkoła historii idei, „Aletheia” 1987, nr 1, s. 121-153 (ogłoszone najpierw w j. ang. On Writing of the History of Ideas. Leszek Kolakowski and the Warsaw School of the History of Ideas, „Critical Philosophy” (Sydney) 1, 1984, nr 2, s. 5-23)

Marksizm i nieudany „skok do królestwa wolności”, w: tenże, Polska, Rosja, marksizm, red. A. Mencwel, Kraków 2011 (Kultura i Myśl Polska. Prace Wybrane Andrzeja Walickiego, 4), s. 397-446

Marksizm i skok do królestwa wolności. Dzieje komunistycznej utopii, Warszawa 1996

Mesjanistyczne koncepcje narodu i późniejsze losy tej tradycji, w: Idee i koncepcje narodu w polskiej myśli politycznej czasów porozbiorowych, red. J. Goćkowski, A. Walicki, Warszawa 1977, s. $84-107$

Mesjanizm Adama Mickiewicza w perspektywie porównawczej, Warszawa 2006

Mesjanizm nie na nasze czasy [cz. 1], [wywiad udzielony S. Dudzie, T. Jerzewskiemu i K. Ołdakowskiemu SI], „Przegląd Powszechny” 2010, nr 9, s. 10-25

Między filozofia, religia i polityką. Studia o myśli polskiej epoki romantyzmu, Warszawa 1983

Moje sprawy z Marksem i marksizmem, wywiad udzielony J. Dobieszewskiemu i P. Kozłowskiemu, w: P. Kozłowski, Spotkania $z$ Andrzejem Walickim, Warszawa 2021

Naród, nacjonalizm, patriotyzm, wstęp A. Mencwel, Kraków 2009 (Kultura i Myśl Polska. Prace Wybrane Andrzeja Walickiego, 1)

Od narodnictwa do leninizmu, w: tenże, Idea wolności u myślicieli rosyjskich. Studia z lat 1955-1959, Kraków 2000 (Jagiellońskie Studia z Filozofii Rosyjskiej, 3), s. 253-273

Od projektu komunistycznego do neoliberalnej utopii, Kraków 2013

Paradoxes of Jaruzelski's Poland, „Archives Européennes de Sociologie” 26, 1985, nr 2, s. 167-191 (wersja polska w tomie Polskie zmagania $z$ wolnością. Widziane $z$ boku, Kraków 2000, s. 11-34)

Philosophy and Romantic Nationalism. The Case of Poland, Oxford 1982; Notre Dame (Ind.) 1994

Pisma filozoficzne Cieszkowskiego z lat 1838-1842 w kontekstach intelektualnych epoki, w: A. Cieszkowski, Prolegomena do historiozofii. Bóg i palingeneza oraz inne pisma filozoficzne $z$ lat 1838-1842, oprac. i wstęp A. Walicki, Warszawa 1972

Polityka i religia w koncepcjach filozoficznych Bronisława Trentowskiego, w: B. Trentowski, Wybór pism filozoficznych $z$ lat 1842-1845, wyd. 2, Warszawa 2014, s. VII-XXXV

Polska debata nad totalitaryzmem. Interpretacje i diagnozy, „Przegląd Polityczny” 2006, nr 76, s. $128-131$

Polska, Rosja, marksizm. Studia z dziejów marksizmu i jego recepcji, Warszawa 1983 
Polska, Rosja, marksizm, red. A. Mencwel, Kraków 2011 (Kultura i Myśl Polska. Prace Wybrane Andrzeja Walickiego, 4)

Polskie zmagania $z$ wolnością. Widziane $z$ boku, Kraków 2000

Posłowie, w: tenże, Idea wolności u myślicieli rosyjskich. Studia z lat 1955-1959, Kraków 2000 (Jagiellońskie Studia z Filozofii Rosyjskiej, 3), s. 293-306

Problem religii w ideologiach „Polski odradzającej się”: od deizmu do mesjanizmu, w: tenże, Mesjanizm Adama Mickiewicza w perspektywie porównawczej, Warszawa 2006, s. 45-124

Rewolucja Październikowa jako projekt komunistyczny, w: Totalitaryzmy XX wieku. Idee, instytucje, interpretacje, red. W. Kozub-Ciembroniewicz i in., Kraków 2010, s. 123-132

Rewolucyjność kwestii polskiej i wynikające stąd konsekwencje, w: tenże, Polska, Rosja, marksizm, red. A. Mencwel, Kraków 2011 (Kultura i Myśl Polska. Prace Wybrane Andrzeja Walickiego, 4), s. $165-175$

Rosyjska filozofia i myśl społeczna od oświecenia do marksizmu, Warszawa 1973 (wyd. 2 poszerzone, Kraków 2005 (Jagiellońskie Studia z Filozofii Rosyjskiej, 10)

Samowładztwo rozumu i objawy filozofi słowiańskiej, w: K. Libelt, Samowładztwo rozumu i objawy filozofii słowiańskiej, wyd. 2, oprac. i wstęp. A. Walicki, Warszawa 2014

Sprawiedliwość okresu przejściowego $i$ walki polityczne, w: tenże, Polskie zmagania $z$ wolnościa. Widziane z boku, Kraków 2000, s. 133-174

Stanisław Brzozowski - drogi myśli, Warszawa 1977

Totalitaryzm, czyli o potrzebie rozrachunków uczciwych, „Polityka Polska” 1990, nr 1(15), s. 10-16

Totalitaryzm i posttotalitaryzm. Próba definicji, w: Społeczeństwa posttotalitarne. Kierunki przemian, red. Z. Sadowski, Warszawa 1991 (materiały z konferencji odbytej w listopadzie $1990 \mathrm{r}$. w Radziejowicach pod Warszawą), s. 13-26 (ten sam tekst w: A. Walicki, Polskie zmagania z wolnością. Widziane z boku, Kraków 2000, s. 97-112)

The Troubling Legacy of Roman Dmowski, „East European Politics and Societies” 1, 1999, s. 12-46

Trzy patriotyzmy. Trzy tradycje patriotyzmu polskiego i ich znaczenie wspótczesne, Warszawa 1991

„Tygrys” $i$ „odwilż”, w: tenże, Spotkania z Miłoszem, Londyn 1985, s. 47-71

$W$ kregu konserwatywnej utopii. Struktura i przemiany rosyjskiego słowianofilstwa, Warszawa 2002

Warszawska szkoła historyków idei: kilka sprostowań i pytań, „Przegląd Polityczny” 2015, nr 129, s. $54-67$

Zarys myśli rosyjskiej. Od oświecenia do renesansu religijno-filozoficznego, Kraków 2005 (wyd. ang.: The Flow of Ideas. Russian Thought from the Enlightenment to the Religious-Philosophical Renaissance, tłum. J. Kozak, H. Andrews-Rusiecka, Frankfurt am Main 2015)

Zniewolony umyst po latach, Warszawa 1993

Zrozumieć przeszłość, „Zdanie” 1990, nr 2-3, s. 2-8

\section{Opracowania}

B. Anderson, Imagined Communities. Reflections on the Origin and Spread of Nationalism, London 1983 (wyd. pol.: Wspólnoty wyobrażone. Rozważania o źródłach i rozprzestrzenianiu się nacjonalizmu, tłum. S. Amsterdamski, Kraków 1997)

Archiwum warszawskiej szkoły historii idei, wstęp, red. i oprac. A. Karalus, P. Parszutowicz, Warszawa 2015

R. Aron, Widz i uczestnik, rozmawiają J.-L. Missika, D. Wolton, tłum. A. Zagajewski, Warszawa 1993

B. Baczko, Kryptoproblemy $i$ historyzm, w: tenże, Człowiek $i$ światopoglady, Warszawa 1965, s. $373-418$

I. Berlin, Dwie koncepcje wolności i inne eseje, wybór i oprac. J. Jedlicki, tłum. H. Bartoszewicz i in., posł. P. Śpiewak, Warszawa 1991

I. Berlin, Rosyjscy myśliciele, tłum. S. Kowalski, posł. A. Walicki, Warszawa 2003 
A. Besançon, Czy Gorbaczow może zmienić system?, w: tenże, Świadek wieku. Wybór publicystyki $z$ pierwszego i drugiego obiegu, t. 1, oprac. F. Memches, Warszawa 2006, s. 313-380 (przedruk z „Encounter” 1987, nr 5-6)

G. Besier, Das Europa der Diktaturen. Eine neue Geschichte des 20. Jahrhunderts, Münich 2006

N. Bierdiajew, Problemy komunizmu, tłum. M. Reutt, Warszawa 1937

Z. Brzeziński, The Grand Failure. The Birth and Death of Communism in the Twentieth Century, New York 1989 (wyd. pol.: Wielkie bankructwo. Narodziny i śmierć komunizmu w XX wieku, Paryż 1990, Biblioteka „Kultury”, 456)

Z. Brzeziński, M. Kornat, Pięćdziesiąt lat później, „Przegląd Polityczny” 2006, nr 79/80, s. 141

Brzozowski. Przewodnik Krytyki Politycznej, Warszawa 2011

A. Cieszkowski, Prolegomena do historiozofii. Bóg i palingeneza oraz inne pisma filozoficzne z lat 1838-1842, oprac. i wstęp A. Walicki, Warszawa 1972

A.J. Czartoryski, Rozważania o dyplomacji, tłum. J.M. Kłoczowski, oprac. i studium: Reforma dyplomacji i legitymizm narodów M. Kornat, Kraków 2011

A. Friszke, Jakim państwem była Polska po 1956 r.? Spór historyków, „Więź” 1996, nr 2, s. 131-146

A. Gleason, Totalitarianism, Oxford 1995

W. Gurian, The Totalitarianism as Political Religion, w: Totalitarianism, red. C.J. Friedrich, Cambridge (MA) 1954, s. 119-140

V. Havel, Siła bezsilnych $i$ inne eseje, wybór A.S. Jagodziński, Warszawa 2011.

M. Heller, Historia imperium rosyjskiego (1997), tłum. E. Melech, T. Kaczmarek, Warszawa 1999

A. Hertz, Drużyna wodza, „Przegląd Socjologiczny” 5, 1937, nr 3-4, s. 599-692 (powtórzone w jego wydanym pośmiertnie zbiorze: Szkice o totalitaryzmie, Warszawa 1994)

A. Hertz, Militaryzacja stronnictwa politycznego, „Przegląd Socjologiczny” 4, 1936, nr 1-2, s. 60-109

A. Hertz, Posłannictwo wodza, „Przegląd Socjologiczny” 4, 1936, nr 3-4, s. 341-413

D. Jarosz, Polacy a stalinizm 1948-1956, Warszawa 2000

J. Jedlicki, Supet Walickiego, „Przegląd Polityczny” 2000, nr 45, s. 19

W. Karpiński (pod pseud. K. Opaliński), O duchu bezprawia, „Kultura” 1974, nr 12(327), s. 9-23

J.J. Kirkpatrick, Fenomen polityki Ronalda Reagana, Warszawa 1989

Z. Klarnerówna, Słowianofilstwo w literaturze polskiej, Warszawa 1926

L. Kołakowski, Główne nurty marksizmu. Powstanie, rozwój, rozkład, Londyn 1988 (wyd. 1, t. 1-3, Paryż 1976-1978)

L. Kołakowski, Marksistowskie korzenie stalinizmu, w: tenże, Czy diabeł może być zbawiony i 27 innych kazań, Londyn 1984, s. 244-259

M. Kornat, Andrzej Walicki i doświadczenie totalitaryzmu. O użyteczności historii idei, „Przegląd Polityczny" 2010, nr 102, s. 60-79

M. Kornat, Bolszewizm, totalitaryzm, rewolucja, Rosja. Początki sowietologii i studiów nad systemami totalitarnymi w Polsce (1918-1939), t. 1-2, Kraków 2003-2004

M. Kornat, Marksizm a totalitaryzm. Wokół stanowiska Andrzeja Walickiego, „Przegląd Filozoficzny" (nowa seria) 20, 2011, nr 1(77), s. 47-61

S. Kotkin, Armageddon Averted. The Soviet Collapse 1970-2000, Oxford 2001

Z. Krasnodębski, Polityka i moralność - w ogóle, u nas i gdzie indziej, „Znak” 1997, nr 7, s. 4-19

J. Kucharzewski, Od białego caratu do czerwonego, t. 1: Epoka Mikołaja I, Warszawa 1923; t. 2, cz. 1: Geneza maksymalizmu, t. 2, cz. 2: Dwa światy, Warszawa 1925; t. 3: Lata przełomu, Romanow, Pugaczew czy Pestel, Warszawa 1928; t. 4: Wyzwalanie ludów, Warszawa 1931; t. 5: Terroryści, Warszawa 1931; t. 6: Rządy Aleksandra III. Ku reakcji, Warszawa 1933; t. 7: Tryumf reakcji, Warszawa 1935; wyd. powojenne nakładem PWN: t. 1: Epoka mikołajowska, red. A. Szwarc, P. Wieczorkiewicz, Warszawa 1998; t. 2: Geneza maksymalizmu. Dwa światy, red. A. Szwarc, P. Wieczorkiewicz, Warszawa 1998; t. 3: Lata przełomu. Romanow, Pugaczow czy Pestel, red. A. Szwarc, P. Wieczorkiewicz, Warszawa 1999; t. 4: Wyzwalanie ludów, red. F. Nowiński 
Warszawa 1999; t. 5: Terroryści, red. F. Nowiński, Warszawa 2000; t. 6: Rządy Aleksandra III. Ku reakcji, red. F. Nowiński, Warszawa 2000; t. 7: Triumf reakcji, red. A. Szwarc, P. Wieczorkiewicz, Warszawa 2000 (wyd. ang. skrócone: The Origin of Modern Russia, New York 1948; polska edycja tej książki: Od białego do czerwonego caratu, przedm. O. Halecki, Londyn 1958, wyd. 2: 1986, wyd. 3: 1989)

J. Lenczowski, Od Reagana do Gorbaczowa (wywiad), „Kultura” 1989, nr 1-2, s. 40-49

K. Libelt, Samowładztwo rozumu i objawy filozofii słowiańskiej, Warszawa 1967

P. Machcewicz, Zmiana czy kontynuacja? Polska przed i po Październiku '56, w: PRL - trwanie i zmiana, red. D. Stola, M. Zaremba, Warszawa 2003, s. 119-158

M. Malia, Under the Western Eyes. From the Bronze Horseman to the Lenin Mausoleum, Harvard 1999

A. Mencwel, Warszawska szkoła historyków idei-powstanie, przekształcenia, kontynuacje, „Przegląd Humanistyczny" 2012, nr 3, s. 5-38

A. Michnik, Kto się boi, powinien spać pod pierzyną, „Zdanie” 2021, nr 1, s. 3-16

A. Mickiewicz, Dzieła wszystkie, t. 9: Literatura słowiańska, oprac. L. Płoszewski, Warszawa 1935

A. Nowak, Republika i imperium: dwa patriotyzmy, w: Formuly patriotyzmu w Europie Wschodniej i Środkowej od nowożytności do wspótczesności, red. A. Nowak, A. Zięba, Kraków 2009, s. 77-102

A. Nowak, Republika, Imperium, Modernizacja: trzy wzory polskiego patriotyzmu, „Seminarium Polskiej Akademii Umiejętności” 6, 2011, s. 25-48

A. Pawełczyńska, Głowy hydry: o przewrotności współczesnego zła, Lublin 2004

R. Pipes, Russia under Old Regime, New York 1974 (wyd. pol.: Rosja carów, tłum. J. Bratkiewicz, wstęp i oprac. P.P. Wieczorkiewicz, Warszawa 1990)

R. Pipes, Vixi. Memoirs of a Non-Belonger, New Haven 2003

Prawo międzynarodowe i historia dyplomatyczna, t. 1, red. L. Gelberg, Warszawa 1958

R. Sitek, Warszawska szkoła historii idei: między historią a teraźniejszością, Warszawa 2000

A. Sołżenicyn, Sierpień czternastego, Londyn 1972

R. Szporluk, Polska: powstanie teorii i praktyki nowoczesnego narodu, w: tenże, Imperium, narody, komunizm. Wybór esejów, wstęp i oprac. A. Nowak, tłum. S. Czarnik, A. Nowak, Kraków 2003

P. Sztompka, Socjologia. Analiza społeczeństwa, Kraków 2002

J. Szujski, O fałszywej historii jako mistrzyni fałszywej polityki: rozprawy i artykuły, red. H. Michalak, Warszawa 1991

P. Śpiewak, W pół drogi. Warszawska szkoła historyków idei, „Więź” 1981, nr 5, s. 39-48

H. Świda-Ziemba, Stalinizm i społeczeństwo polskie, w: Stalinizm, red. J. Kurczewski, Warszawa 1989, s. 15-95

H. Świda-Ziemba, Stalinizm i społeczeństwo polskie, Warszawa 1991

Y. Tamir, Liberal Nationalism, Princeton 1993

B. Trentowski, Podstawy filozofii uniwersalnej; Wstęp do nauki o naturze, z oryg. niem. tłum. M. Żułkoś-Rozmaryn, przyp. J. Garewicz, wstęp A. Walicki, Warszawa 1978

B. Trentowski, Stosunek filozofii do cybernetyki oraz Wybór pism filozoficznych z lat 1842-1845, wstęp i koment. A. Walicki, Warszawa 1974

R.C. Tucker, Stalin in Power. The Revolution from Above 1928-1941, New York 1990

J. Ujejski, Dzieje polskiego mesjanizmu do powstania listopadowego wtacznie, Warszawa 1931

R.M. Weaver, Ideas Have Consequences, Chicago 1948

Wokół Andrzeja Walickiego. Almanach myśli rosyjskiej, red. J. Dobieszewski, J. Skoczyński, M. Bohun, Warszawa 2009

Wokół myśli Stanisława Brzozowskiego, red. A. Walicki, R. Zimand, Kraków 1974

J. Żakowski, Ostatni wywiad z prof. Walickim: Jesteśmy pół na pół, „Polityka” 16-22 IX 2020 


\section{Andrzej Walicki as a historian of ideas}

This article presents Andrzej Walicki's contribution to the Polish historiography of ideas. $\mathrm{He}$ is remembered above all as a historian of Russian political, social, and religious thought. However, it would be impoverishing to stop at this statement. In Walicki's intellectual biography, we find at least five other fields of reflection that he practised throughout his life. These were: (1) Polish political and social thought in the Romanticism; (2) ideas of the nation in Polish postpartition political thought; (3) Marxism and its variants; (4) the problem of totalitarianism as the most radical form of human enslavement in the modern era; (5) varieties of liberalism as a political concept. One could also mention his interest in the phenomenon of the Polish intelligentsia and its mission in the national life of the post-partition era and the realities of the twentieth century, dramatic for the Polish people. The last two areas have barely been mentioned. The author has attempted to present Walicki's achievements as that of a historian of Russian and Polish thought, an advocate of totalitarianism theory and a historian of Marxism.

The most important conclusions are as follows: As a Pole, Walicki made a significant contribution to the study of Russian thought. This, however, was not easy in the realities of People's Poland (and in the situation of Poland's dependence on the USSR). In particular, his book $W$ kregu konserwatywnej utopii (In the Circle of Conservative Utopia) remains a significant achievement. His synthesis entitled Rosyjska filozofia i myśl społeczna od oświecenia do marksizmu (Russian Philosophy and Social Thought from Enlightenment to Marxism) is undoubtedly a valuable, if not the most important in world literature, reconstruction of Russian philosophical, religious, and political ideas. Walicki rediscovered the concepts of Polish Romanticism - a poorly recognised 'national philosophy' and placed Mickiewicz's Messianism against the European background. He showed various ideas of the 'mission' of the Polish nation in history. He independently thought through Marx's intellectual heritage, subjecting it to critical analysis. He saw the source of totalitarianism in Marxism, which he strongly emphasised in his synthetic work Marksizm i skok do królestwa wolności (Marxism and the Leap to the Kingdom of Freedom). In his view, totalitarianism was not only a repressive dictatorship but a phenomenon that enslaves 'from within' through the action of the phenomenon of 'new faith'. It was he who coined the notion of 'detotalitarianism' as a process of decomposition of the totalitarian order. Undoubtedly, Andrzej Walicki remains the most creative personality of this intellectual formation called the 'Warsaw School of historians of ideas'.

Marek Kornat (ur. 1971) - prof. dr hab., pracownik Instytutu Historii im. Tadeusza Manteuffla Polskiej Akademii Nauk, wykładowca Wydziału Prawa i Administracji oraz Nauk Historycznych Uniwersytetu Kardynała Stefana Wyszyńskiego. Zajmuje się historią polskiej dyplomacji i stosunków międzynarodowych w XX w. oraz dziejami polskiej myśli politycznej i sowietologii. Autor m.in.: Polska 1939 roku wobec paktu Ribbentrop-Mołotow. Problem zbliżenia niemiecko-sowieckiego w polityce zagranicznej II Rzeczypospolitej, Warszawa 2002; Bolszewizm, totalitaryzm, rewolucja, Rosja. Poczatki sowietologii i studiów nad systemami totalitarnymi w Polsce (1918-1939), t. 1-2, Kraków 2003-2004; Polen zwischen Hitler und Stalin. Studien zur polnischen Außenpolitik in der Zwischenkriegszeit, Berlin 2012; Polityka zagraniczna Polski 1938-1939. Cztery decyzje Józefa Becka, Gdańsk 2012; Wacław Grzybowski. Ambasador w Moskwie (1936-1939). Biografia polityczna, Warszawa 2016; Józef Beck. Biografia, Kraków 2020 (wraz z Mariuszem Wołosem); za tę ostatnią książkę otrzymał Nagrodę Książka Historyczna Roku im. Karola Modzelewskiego (2021) oraz Nagrodę Ministra Spraw Zagranicznych (również w 2021).E-mail: m_kornat@o2.pl 